DOI: 10.32089/WBH.phw.2019.2(268).0004

orcid.org/0000-0002-9820-6140

BARTOSZ KAPUŚCIAK

\title{
Wywiad wojskowy czy polityczny? Zainteresowanie Zarządu II Sztabu Generalnego Wojska Polskiego „kierunkiem watykańskim”
}

Utrzymanie poprawnych kontaktów $z$ tymi ośrodkami ma dla mnie znaczenie praktyczne. Brak przeciwdziatania ze strony tych księży pozwala mi na pewniejsze wchodzenie $w$ środowisko bez obawy prób izolacji, jak ma to miejsce w odniesieniu do pracowników Ambasady $i$ innych placówek stużbowych $w$ Rzymie. Tego elementu nie wolno tracić $z$ oczu...

płk Franciszek Mazurek, ps. „Barcz”

Wywiad wojskowy PRL, który w zakresie swoich zadań miał przede wszystkim zdobywać materiały dot. uzbrojenia i stacjonowania wojsk NATO, prowadził także działania polityczne, wymierzone m.in. w Kościół katolicki. Wynikało to z zapotrzebowania władz komunistycznych w Warszawie, które Kościół katolicki uznawały za głównego wroga ideologicznego. Zainteresowanie władz państwowych nasiliło się szczególnie w czasie pontyfikatu Jana Pawła II. Wybór Karola Wojtyły na biskupa Rzymu dał, według wywiadu wojskowego, „niewątpliwie potężny impuls w kierunku aktywizacji kościoła [sic!] w Polsce w ogóle, a polskiego środowiska kościelnego

1 Cyt. Archiwum Instytutu Pamięci Narodowej (dalej: AIPN), Zarząd II SG WP, 2602/27084, Załącznik nr 1 do pisma nr 8/83 dot. wstępnej charakterystyki polskiego środowiska duchownego na terenie Rzymu, [Rzym]16 VIII 1983 r., k. 120. Materiały dot. opisanej poniżej sprawy dotychczas znajdowały się w zbiorze wyodrębnionym Archiwum IPN, popularnie zwanym „zetką". Pokazuje to działanie Wojskowych Służb Informacyjnych, które po powstaniu Instytutu Pamięci Narodowej w 1998 r. pewne materiały przekazały do zbioru zastrzeżonego pod pretekstem zagrożenia bezpieczeństwa państwowego, mimo iż nie wychodzą one poza ustawowy 
na terenie Rzymu (w tym i Watykanu) w szczególności”2. Zarząd II Sztabu Generalnego WP, który prowadził zadania wywiadowcze, wchodził w ten sposób w zakres zainteresowań wywiadu cywilnego ${ }^{3}$.

Co najmniej od początku lat siedemdziesiątych w Rzymie z ramienia Zarządu II Sztabu Generalnego WP działała rezydentura krypt. „Góra”4. Dodatkowo wywiad wojskowy prowadził podrezydenturę w Mediolanie - krypt. „Dolina” - kierowaną bezpośrednio przez podrezydenta, podlegającą pod rezydenturę rzymską. Współpracownikiem ${ }^{5}$ rezydentury krypt. „Góra” w latach 1977-1982 był

rok 1990 i dot. działań prowadzonych wobec Kościoła katolickiego. Likwidacja tzw. zbioru zastrzeżonego pozwoliła rozszerzyć badania nad aparatem represji zarówno wojskowym, jak i cywilnym w Polsce Ludowej. Sprawa samej współpracy abp. Głodzia i innych duchownych przebywających w okresie 1978-1990 w Watykanie oraz działania wywiadu wojskowego na kierunku watykańskim zostały opisane w dodatku do „Rzeczpospolitej”, zob. T. Krzyżak, A. Gajcy, Armia PRL kontra Papież, „Plus Minus” dodatek do „Rzeczpospolitej”, 9-10 VI 2018, s. 4-9 oraz T. Krzyżak, Armia zagląda Papieżowi do talerza, „Plus Minus” dodatek do „Rzeczpospolitej”, 30 VI - 1 VII 2018, s. 13-15. Temat ten swego czasu opisywany był także przez Marka Mądrzaka. Pytanie tylko, dlaczego autor opisywał rzeczy, które wówczas nie dość, że były ściśle tajne, to jeszcze trzymane w zbiorze wyodrębnionym? Zob. M. Mądrzak, Generał Leszek Sławoj Głódź - pierwsze szlify, http://nowa.gazetaobywatelska.info/materials/554b94fbeef861852eba9c19 (dostęp: 23 III 2017 r.); idem, Ojciec Hejmo, czyli blacha na dach kościoła (Domu Pielgrzyma?), http://nowa.gazetaobywatelska.info/materials/554b94fbeef861852eba9c47 (dostęp: 23 III 2017 r.); idem, Proboszcz Kazimierz Lorek w latach studenckich, http://nowa.gazetaobywatelska.info/materials/554b94fbeef861852eba9c46 (dostęp: 23 III 2017 r.).

2 Tak w oryginale. Cyt. AIPN, Zarząd II SG WP, 2602/27084, Załącznik nr 1 do pisma nr 8/83 dot. wstępnej charakterystyki polskiego środowiska duchownego na terenie Rzymu, [Rzym] 16 VIII 1983 r., k. 115.

3 W tym czasie realizował te zadania Departament I MSW w ramach rezydentury krypt. „Baszta”, zob. W. Bagieński, Wywiad PRL w Rzymie, „Biuletyn IPN” 2017, nr 1-2, s. 110-127; W. Bułhak, Watykan i szpiedzy z awansu społecznego. Próba portretu zbiorowego kierownictwa wydziału „natowsko-amerykańskiego" i rzymskiej rezydentury „Baszta” Departamentu I (wywiadu) MSW PRL w okresie poprzedzającym pontyfikat Jana Pawła II [w:] Służby wywiadowcze jako narzędzie realizacji polityki państwa w XX wieku. Wybrane zagadnienia, red. L. Pawlikowicz, R. Zapart, Rzeszów 2014, s. 172-209.

4 Rezydentura była zorganizowaną nieetatową komórką o zmiennym składzie osobowym, wykonującą samodzielne zadania wywiadowcze na określonym terenie poza granicami kraju zlecane przez centralę wywiadu wojskowego. Rezydentura mogła przyjąć formę legalną (działała z pozycji przykrycia, w jej skład wchodzili pracownicy attachatów wojskowych oraz wywiadowcy pod przykryciem i współpracownicy zatrudnieni na placówkach zagranicznych) i nielegalną (agenturalną - z pozycji nielegalnej, w jej skład wchodzili pracownicy kadrowi, nielegalni pracownicy wywiadu, nielegałowie i agenci). Rezydenturom podlegały czasami, ze względu na teren bądź inne przyczyny organizacyjne, mniejsze komórki wywiadowcze zwane podrezydenturami. Zob. S. Cenckiewicz, Długie ramię Moskwy. Wywiad wojskowy Polski Ludowej 1943-1991 (wprowadzenie do syntezy), Poznań 2011, s. 484-485; W. Bagieński, Dwa słowniki wywiadu wojskowego PRL z 1970 i 1978 r. [w:] Studia na wywiadem i kontrwywiadem Polski w XX wieku, t. 1, red. W. Skóra, P. Skubisz, Szczecin 2012, s. 719, 721-722.

5 Współpracownik wywiadu wojskowego to z definicji obywatel polski pozyskany do współpracy z wywiadem wojskowym, typowany spośród osób pracujących w instytucjach cywilnych 
Andrzej Podczaszy ps. „Gość”’ Znał go z akt kpt. Jerzy Sumiński, oficer Wydziału VI Szefostwa Wojskowej Służby Wewnętrznej (WSW), który zabezpieczał wywiad wojskowy, a który uciekł 6 czerwca 1981 r. za granicę . Sumiński podejrzewał Podczaszego o kontakt z Oddziałem IV (anglo-amerykańskim) Zarządu II SG WP. . „Gość” w ramach rezydentury miał za zadanie rozpracowywanie włoskiego Ministerstwa Spraw Zagranicznych (MSZ) oraz stowarzyszenia włoskich firm przemysłu lotniczego, przeprowadzanie penetracji wystaw i targów, gdzie można pozyskać źródła i zdobyć materiały interesujące wywiad wojskowy PRL9. Podczaszy z powodu pełnionych funkcji służbowych przedstawiciela Polskich Linii Lotniczych (PLL) „LOT” nawiązał znajomości z ks. Henrykiem Kietlińskim ${ }^{10}$,

lub wojskowych, działający za granicą i w kraju z tzw. pozycji legalnej. Zob. S. Cenckiewicz, Długie ramię Moskwy..., s. 487; W. Bagieński, Dwa słowniki wywiadu wojskowego..., s. 727.

6 Andrzej Podczaszy (ur. 24 II 1935 r. w Albau we Francji) członkiem PZPR został w 1959 r. Z wywiadem wojskowym współpracował od 1961 r. do co najmniej 1990 r. Oficjalnie pełnił funkcję przedstawiciela PLL „LOT” we Francji w latach 1961-1965, w Kairze w latach 19651968, w Libanie w latach 1971-1973 oraz we Włoszech w latach 1977-1982. Wcześniej pracował w charakterze kasjera kas zagranicznych w Oddziale Sprzedaży Biletów PLL „LOT” i jednocześnie pełnił funkcję sekretarza Oddziałowej Organizacji Partyjnej. AIPN, Zarząd II SG WP, 2602/22366, Analiza współpracownika ps. „Gość”, [Warszawa] 8 VII 1981 r., k. 237.

7 O Sumińskim szerzej: S. Cenckiewicz, Atomowy szpieg. Ryszard Kukliński i wojna wywiadów, Poznań 2014, s. 303-323; A. Wiorko, Dezercja, która wstrzasnęła przełożonymi, „Biuletyn Informacyjny AK” 2016, nr 9, s. 129-135; Normatywy Wojskowej Służby Wewnętrznej (1957-1990), wyb., wst. i opr. B. Kapuściak, Katowice-Kraków 2019, s. 37-38. Zob. także poszczególne materiały dot. Sumińskiego: AIPN, Zbiór akt personalnych żołnierzy pełniących służbę w cywilnych i wojskowych organach bezpieczeństwa państwa (w tym żołnierzy represjonowanych z motywów politycznych) oraz pracowników cywilnych wojska, 2300/948, Akta personalne Jerzego Sumińskiego; AIPN, Szefostwo Wojskowej Służby Wewnętrznej (dalej: SWSW), 2386/16529, Akta śledztwa przeciwko Jerzemu Józefowi Sumińskiemu, s. Bronisława z Szefostwa WSW art. $304 \$ 3$ i 122 kk, t. 1; AIPN, SWSW, 2386/19530, Akta śledztwa przeciwko Jerzemu Józefowi Sumińskiemu, s. Bronisława z Szefostwa WSW art. 304 \$ 3 i 122 kk, t. 2; AIPN, Zarząd II SG WP, 2602/16857, Plany pracy Oddziału I Zarządu II SG WP, k. 291-301 (poszczególne meldunki dot. znajomości spraw i osób przez kpt. Sumińskiego).

8 AIPN, Zarząd II SG WP, 2602/22366, Analiza współpracownika ps. „Gość”, [Warszawa] 8 VII 1981 r., k. 236-237.

9 AIPN, Zarząd II SG WP, 2602/22366, Zadania wywiadowcze dla „Gościa” do realizacji w 1980 r., [Rzym] 14 II 1980 r., k. 206-207.

10 Ksiądz Henryk Kietliński (ur. 6 XI 1932 r. w Nowinach - zm. 4 III 2017 r. w Warszawie). Pallotyn (śluby zakonne przyjął w 1951 r.), w latach 1971-1977 przebywał w Rzymie jako konsulator generalny Stowarzyszenia Apostolstwa Katolickiego, w latach 1978-1984 pełnił funkcję prowincjała Stowarzyszenia Pallotynów w Polsce. Zarejestrowany przez Wydział VI Departamentu I MSW w charakterze kontaktu operacyjnego ps. „Etli” o nr 46370. Wyrejestrowany ze względu na powrót do kraju w 1978 r., materiały o sygn. 14632/I złożono do archiwum Biura „C” MSW, które następnie zmikrofilmowano (sygn. 12822/1). Następnie zarejestrowany przez Wydział III Departamentu IV MSW w charakterze kandydata na tajnego współpracownika o $\mathrm{nr} 69419$. W $1986 \mathrm{r}$. zrezygnowano z pozyskania, a materiały o sygn. 19687/I-k złożono do archiwum Biura „C” MSW. Zob. AIPN, MSW, 00200/273, Kietliński 
z ks. Ryszardem Karpińskim ${ }^{11}$, ks. Marianem Burniakiem ${ }^{12}$ oraz ks. Stanisławem Dziwiszem ${ }^{13}$. Dobre relacje z tymi księżmi nie zostały wykorzystane przez wywiad wojskowy ${ }^{14}$. Wpłynęła na to zapewne sama ocena Andrzeja Podczaszego, który jako współpracownik opiniowany był przez centralę wywiadu negatywnie ${ }^{15}$.

Henryk; AIPN, Ministerstwo Spraw Wewnętrznych (dalej: MSW), 001043/1820/J, Kietliński Henryk; AIPN, MSW, 2911/1, Karta o symbolu E-14/1 z kartoteki ogólnoinformacyjnej dot. Henryka Kietlińskiego; AIPN, MSW, 2911/1, Karta o symbolu E-16 z kartoteki ogólnoinformacyjnej dot. Henryka Kietlińskiego.

11 Biskup Ryszard Karpiński (ur. 28 XII 1935 r. w Rudzienku) doktor nauk teologicznych, święcenia kapłańskie przyjął w 1959 r. W latach 1970-1971 prefekt w Wyższym Seminarium Duchownym w Lublinie, w latach 1971-1985 pracownik Komisji ds. Migracji i Turystyki w Rzymie, w latach 1985-2011 biskup pomocniczy lubelski, od 2011 r. biskup senior archidiecezji lubelskiej. Zarejestrowany przez Wydział IV KW MO do nr 32376. Zob. Archiwum Instytutu Pamięci Narodowej w Lublinie (dalej: AIPN Lu), Wydział ds. Wyznań (dalej: Wds.W), 173/119, Akta osobowe księdza biskupa Ryszarda Karpińskiego; WUSW w Lublinie, 0024/1882, Karpiński Ryszard; AIPN Lu, WUSW w Lublinie, 00226/1, Karta o symbolu E-14 z kartoteki ogólnoinformacyjnej dot. Ryszarda Karpińskiego.

12 Ksiądz Marian Burniak (ur. 23 XII 1935 r. w Złotnikach) święcenia kapłańskie przyjął w 1963 r. Kapłan Towarzystwa Chrystusowego dla Polonii Zagranicznej, w latach 1961-1963 studiował na Papieskim Uniwersytecie Gregoriańskim w Rzymie, w latach 1963-1964 pracownik sekretariatu abp. Józefa Gawliny w Rzymie, w latach 1964-1970 współpracownik Centralnego Ośrodka Duszpasterstwa ds. Emigracji Polskiej przy delegacie prymasa Polski bp. Władysławie Rubinie w Rzymie, w latach 1970-2007 prokurator generalny Towarzystwa Chrystusowego dla Polonii Zagranicznej; w tym czasie także duszpasterz Polonii włoskiej (1970-2003) oraz redaktor biuletynu „Duszpasterz Polaków we Włoszech” (1984-1989). W 1984 r. zarejestrowany przez Wydział XI Departamentu I MSW do Segregatora Materiałów Wstępnych krypt. „Bumar” o nr 2027. Materiały w 1989 r. zniszczono. AIPN, MSW, 2911/1, Karta o symbolu EO-4-A/77 z kartoteki ogólnoinformacyjnej dot. Mariana Burniaka; AIPN, MSW, 01746/4, Postanowienie o zniszczeniu akt sprawy archiwalnej departamentu I MSW, Warszawa 15 II 1989 r., k. 529-530.

13 Kardynał Stanisław Dziwisz (ur. 27 IV 1939 r. w Rabie Wyżnej) doktor nauk teologicznych, święcenia diakonatu przyjął w 1963 r. W latach 1957-1963 studiował w Wyższym Seminarium Duchownym Archidiecezji Krakowskiej, kapelan arcybiskupa metropolity krakowskiego Karola Wojtyły w latach 1966-1978, osobisty sekretarz papieża Jana Pawła II w latach 1978-2005, arcybiskup metropolita krakowski w latach 2005-2016, kardynał prezbiter od 2006 r., od 2016 r. arcybiskup senior archidiecezji krakowskiej. Na temat inwigilacji przez służby PRL zob. katalog IPN, http://katalog.bip.ipn.gov.pl/informacje/95078 (dostęp: 24 VI 2019 r.).

14 AIPN, Zarząd II SG WP, 2602/22366, Sprawozdanie z pracy za okres luty 1977 do dnia 21 I 1982 r., [Warszawa przełom stycznia/lutego 1982 r.], k. 223.

15 „Gość” za pracę operacyjną oceniony był niedostatecznie, a za pracę informacyjną tylko dostatecznie, zob. AIPN, Zarząd II SG WP, 2602/22366, Ocena pracy współpracownika ps. "Gość" za okres pobytu w Rzymie od 15 II 1977 r. do 21 I 1982 r., [Warszawa] 30 IV 1982 r., k. 234. 
Od 1979 r. rezydentem placówki rzymskiej był kmdr por. Czesław Wawrzyniak ps. „Rafał”" ${ }^{16}$ Oficjalnie występował jako attaché przy Ambasadzie PRL. W 1981 r. Wawrzyniak próbował rozpracowywać ks. Tadeusza RakoCzego $^{17}$ wytypowanego na informatora świadomego. Nie udało mu się dokonać werbunku, gdyż centrala wywiadu wojskowego wycofała się z tego „Z powodu wcześniejszego podjęcia sprawy przez MSW”18.

16 Czesław Wawrzyniak (ur. 13 IV 1937 r. w Kunowie, zm. 2 III 2019 r. w Warszawie) członkiem PZPR został w 1960 r. Od 15 VII 1956 r. w Siłach Zbrojnych PRL, najpierw służył w marynarce wojennej, a od 1965 r. został pracownikiem wywiadu wojskowego. Z ramienia Zarządu II SG WP w latach 1970-1974 pełnił funkcję rzeczoznawcy attaché w Paryżu, później starszego oficera Oddziału IV (anglo-amerykańskiego), a następnie w latach 19791983 attaché wojskowego w Rzymie. W latach 1984-1987 pełnił obowiązki szefa Oddziału „K” (krajów europejskich) Zarządu II SG WP. Występował pod nazwiskiem legalizacyjnym Czesław Warecki i pod pseudonimem „Rafał”. Znany był z akt i osobiście kpt. Jerzemu Sumińskiemu. W 1987 r. przeszedł do rezerwy w stopniu komandora. W 1990 r. powrócił do służby, zostając szefem Gabinetu MON, a w latach 1991-1992 szefem Wojskowych Służb Informacyjnych. Ubył ponownie do rezerwy w 1992 r. w stopniu kontradmirała. Do 1965 r. zarejestrowany był przez Wydział III Departamentu II MSW jako tajny współpracownik ps. „Jurek" (brak daty rejestracji, materiały złożono w 1965 r. do archiwum, a w 1984 r. zniszczono, zob. S 12/2006/Zk, Pismo Naczelnika Wydziału Udostępnienia BUiAD IPN w Warszawie dot. Czesława Wawrzyniaka, 10 X 2013 r., k. 43898-43906). AIPN, Zarząd II SG WP, 003419/1, Karta pracownika Zarządu II dot. kmdr. por. Czesława Wawrzyniaka; Centralne Archiwum Wojskowe Wojskowego Biura Historycznego (dalej: CAW-WBH), Teczki Akta Personalnych (dalej: TAP), 1912/02/52, Akta personalne Czesława Wawrzyniaka; AIPN, Zarząd II SG WP, 2602/21755, Akta personalne pomocnicze Czesława Wawrzyniaka; AIPN, Zarząd II SG WP, 2602/28507, Akta personalne pomocnicze Czesława Wawrzyniaka; AIPN, MSW, 2911/1, Karta o symbolu EO-4/62 z kartoteki ogólnoinformacyjnej dot. Czesława Wawrzyniaka; katalog IPN, https://katalog.bip.ipn.gov.pl/informacje/56716 (dostęp: 19 III 2018 r.).

17 Biskup Tadeusz Rakoczy (ur. 30 III 1938 r. w Gilowicach) w latach 1957-1963 studiował w Wyższym Seminarium Duchownym Archidiecezji Krakowskiej, święcenia prezbiteratu przyjął w 1963 r., w październiku 1978 r. papież Jan Paweł II powołał go do pracy w Stolicy Apostolskiej, wspólnie z ks. Józefem Kowalczykiem (rejestrowany przez Departament I MSW jako kontakt informacyjny ps. „Cappino”, zob. C. Gmyz, SB: „Cappino” to źródło sprawdzone, https://www.rp.pl/artykul/244958-SB---Cappino--to-zrodlo-sprawdzone--.html (dostęp: 30 XII 2018 r.), organizował Polską Sekcję Sekretariatu Stanu (pracował w niej do 1992 r.), w 1979 r. został mianowany honorowym kapelanem, w 1987 r. prałatem papieskim, od 1992 r. biskupem diecezjalnym bielsko-żywieckim, a od 2013 r. biskupem seniorem tejże diecezji. Zarejestrowany został przez Wydział III Departamentu I MSW dopiero 20 II 1986 r. w charakterze figuranta Segregatora Materiałów Wstępnych krypt. „Kapro” o nr 95622. Brak informacji co do zainteresowań jego osobą przez służby cywilne w 1981 r., zob. AIPN, MSW, 01591/63, Rakoczy Tadeusz; AIPN, MSW, 2911/1, Karta o symbolu EO-4-A/77 z kartoteki ogólnoinformacyjnej dot. Tadeusza Rakoczego.

18 AIPN, Zarząd II SG WP, 2602/28311, Sprawozdanie rezydenta - kmdr. por. Czesława Wawrzyniaka, ps. „Rafał” z pracy za granicą w Rzymie za okres 15 IX 1979 r. - 1 X 1983 r., 29 X 1983 r., k. 264. Stamtąd też cytat. Zob. także: AIPN, Zarząd II SG WP, 2602/16173, Pismo nr 3/82, 5 III 1982 r., k. 16. 
Od 1982 r. nowym członkiem rezydentury w Rzymie został płk Franciszek Mazurek, ps. „Barcz”19. Oficjalnie płk Mazurek pracował jako kierownik rzymskiej placówki PLL „LOT”20. Był oficerem pracującym pod

19 Mazurek występował pod swoim nazwiskiem, ale miał także nazwisko legalizacyjne „Feliks Dąbrowski”, zob. AIPN, Zarząd II SG WP, 2602/22905, Pismo płk. Bonifacego Gajewskiego do płk. Wiesława Koprowskiego, Warszawa 7 IX 1987 r., k. 182; Pismo płk. Bonifacego Gajewskiego do płk. Bronisława Siemieńskiego, Warszawa 7 IX 1987 r., k. 183.

Pułkownik Franciszek Mazurek (ur. 24 X 1931 r. w Baranowie) członkiem PZPR został w 1954 r. Służbę w „odrodzonym” Wojsku Polskim rozpoczął w 1949 r. jako podchorąży Oficerskiej Szkoły Piechoty. Od 1951 r. w stopniu porucznika został mianowany dowódcą plutonu strzeleckiego w Wyższej Szkole Piechoty, a następnie plutonu wartowniczego. Później skierowano go do Akademii Sztabu Generalnego (ASG) jako słuchacza fakultetu rozpoznawczego. Pracę w wywiadzie wojskowym rozpoczął w 1956 r., gdzie oddelegowano go bezpośrednio po ukończeniu ASG. Do grudnia 1958 r. pracował w Wydziale Romańskim Oddziału Informacyjnego Zarządu II SG WP (nazwa potoczna, używana przez oficerów wywiadu wojskowego. Franciszek Mazurek pełnił służbę w Wydziale 2 Oddziału III Zarządu II SG WP), po czym przeniesiono go na Wydział Dyplomatyczno-Konsularny przy Szkole Głównej Służby Zagranicznej w Warszawie. Po ukończeniu studiów w 1961 r. został skierowany do pracy poza wojskiem, najpierw w Polskim Biurze Podróży „Orbis” (do kwietnia 1962 r.), następnie w MSZ, skąd został oddelegowany na placówkę konsularną do Malmö w Szwecji (czerwiec 1962 - październik 1966). Podlegał wtedy pod Wydział 1 (agenturalny niemiecko-skandynawski) Oddziału I wywiadu wojskowego. W 1962 r. oficer Departamentu II MSW próbował podjąć z Mazurkiem współpracę, jednak kierownictwo Zarządu II SG WP kazało te spotkania zakończyć ze względu na możliwość dekonspiracji. W 1969 r. na krótko Mazurek wrócił na etat wywiadu wojskowego, pełniąc funkcję starszego pomocnika kierownika Zespołu Wojewódzkich Przedstawicieli Oddziału IV (krajowego). W latach 1969-1971 zatrudniony był, pod przykryciem w Centralnym Zarządzie Lotnictwa Cywilnego, a następnie podjął pracę w „Locie”, zajmując m.in. stanowisko kierownika Działu Zagranicznego. W tym czasie wyjeżdżał do Sztokholmu (1969 r.), Kopenhagi (1970 r.), Wiednia (1971 r.), następnie do Brukseli (w okresie 1972-1977). Pracę poza wojskiem kontynuował do 1991 r. na stanowisku kierownika sekcji ds. obsad placówkowych i analiz Wydziału Kadr, a następnie kierownika działu przedstawicielstw zagranicznych PLL „LOT”, kiedy przeszedł w dyspozycję szefa Sztabu Generalnego WP - z tej pozycji typował i rozpracowywał dla Zarządu II SG WP kandydatów na współpracowników oraz umieszczał w PLL „LOT” już zawerbowanych współpracowników Zarządu II SG WP po linii Oddziału „C” (stołecznego). Zob. AIPN, Zarząd II SG WP, 2602/22905, Ocena pracy, [Warszawa] 5 II 1990 r., k. 200-202; Notatka sprawozdawcza z wykonanych zadań w okresie 1990 roku, [Warszawa] 18 XII 1990 r., k. 207-208; AIPN, Zarząd II SG WP, 2602/26657, Sprawozdanie za 1990 rok na kierunku PLL „LOT”, b.m. 19 XII 1990 r., k. 332-334; Notatka dot. sytuacji organizacyjno-kadrowej PLL „LOT”, b.m. 7 XII 1990 r., k. 339-341. 17 VII 1991 r. Mazurek przeszedł do rezerwy w stopniu pułkownika. Zob. CAW, TAP, 1849/95/1472, Teczka personalna Franciszka Mazurka; AIPN, Zarząd II SG WP, 2602/27084, Analiza oficera poza wojskiem płk. Franciszka Mazurka, [Warszawa] 20 VII 1981 r., k. 146; AIPN, Zarząd II SG WP, 2602/22905, Notatka służbowa kpt. Franciszka Mazurka, [Warszawa] 15 VI 1961 r., k. 9-11; Notatka służbowa kpt. Franciszka Mazurka, b.m. 20 VI 1961 r., k. 12-12v. Zob. zadania dla Franciszka Mazurka za lata 1962-1969 oraz 1972-1980 w: AIPN, Zarząd II SG WP, 2602/7520, Teczka pracy „L” B-382 [dot. Franciszka Mazurka ps. „Barcz”], 1962-1969; AIPN, Zarząd II SG WP, 2602/27053, Teczka pracy „Barcz”, 1972[-1980].

20 W związku z zajmowaną funkcją i możliwością wyjazdu do Rzymu Mazurek sprawdzany był przez Departament I MSW. Zob. AIPN, MSW, 01943/603, Mazurek Franciszek (jacket), 
przykryciem ${ }^{21}$, podległym Oddziałowi „K” (krajów europejskich), ale realizował też zadania dla Oddziału „Y” (agenturalnego) ${ }^{22}$. Od początku swojej służby w wywiadzie wojskowym kontrolowany był przez Główny Zarząd Informacji $(\mathrm{GZI})^{23}$, a następnie, po przeformowaniu, przez Wojskową Służbę Wewnętrzną (WSW), której zadaniem było „ochranianie” Zarządu II SG WP. W 1970 r. ze względu na podejrzane kontakty Mazurka z Amerykanami i z powodu zachowania się żony, która w oczach organów WSW kompromitowała go, kontrwywiad wojskowy sugerował zwolnienie „Barcza” z pracy w Zarządzie II SG WP. Nie doszło jednak do tego ${ }^{24}$. Co ciekawe, zachodziło także duże podejrzenie, że został zdekonspirowany i to czterokrotnie, najpierw przez płk. Pawła Monata w 1966 r. $^{25}$, następnie przez ppłk. Mariana Kozłowskiego w 1969 r. ${ }^{26}$, później

1981 r. - tam też legendowany życiorys Mazurka bez wspomnienia o jakiejkolwiek służbie wojskowej, zob. AIPN, MSW, 01943/603, Mazurek Franciszek (jacket), Życiorys, Warszawa 2 III 1981 r., b.p. Placówka PLL „LOT” była mocno obsadzona współpracownikami wywiadu wojskowego, zob. AIPN, Zarząd II SG WP, 2602/26657, Analiza stanu osobowego aparatu wywiadowczego i kandydatów pozostających w zainteresowaniu, b.m. 1 XI 1990 r., k. 335338.

21 Pracownikami kadrowymi pod przykryciem byli oficerowie Zarządu II SG WP, skierowani na podstawie odpowiedniej legendy do pracy w państwowych instytucjach cywilnych w kraju, a także w polskich placówkach za granicą. Okres ich pracy pod przykryciem był zaliczany do służby wojskowej. Zob. AIPN, Biblioteka byłych wojskowych organów bezpieczeństwa państwa polskiego, 2603/6219, Zasady konspiracji oficera wywiadu wojskowego, Oddział Studiów Specjalnych Zarządu II SG WP, Warszawa 1977, s. 22-37. Zob. także: S. Cenckiewicz, Długie ramię Moskwy..., s. 475-488 oraz W. Bagieński, Dwa słowniki wywiadu wojskowego..., s. 697-736.

22 Wcześniej zajmował się państwem włoskim Oddział VIII (romański, występujący tė̇ w dokumentach jako Oddział „S”). Zob. B. Kapuściak, Wywiad wojskowy PRL. JW 3362 i podległe jej jednostki, „Aparat Represji w Polsce Ludowej 1944-1989” 2016, nr 1 (14), s. $131,136-140$.

23 Rejestrowany do sygn. E1/40211 oraz E1/21257, zob. AIPN, Szefostwo WSW, 2386/32517, Karta E-15 dot. Franciszka Mazurka, [Warszawa] 11 VIII 1957 r., k. 10. Sygnatura akt wskazuje, że materiały były proweniencji agenturalnej, nie zachowały się jednak.

24 AIPN, SWSW, 2386/32517, Notatka dot. „M”, [Warszawa] 1 VIII 1970 r., k. 12-13; Meldunek służbowy F. Mazurka, [Warszawa] 15 VII 1971 r., k. 15-17.

25 AIPN, Zarząd II SG WP, 2602/7520, Notatka służbowa mjr. Franciszka Mazurka dot. przebiegu służby w JW 4552, [1966 r.], k. 65-66. O Monacie szerzej: L. Pawlikowicz, Tajny front zimnej wojny. Uciekinierzy z polskich stużb specjalnych 1956-1964, Warszawa 2004, s. 176-214; T. Pióro, Ucieczki oficerów Ludowego Wojska Polskiego w latach 1948-1990, „Więź" 1999, nr 12, s. 124-139; AIPN, MSW, 1666/1196, P. Monat, J. Dille, Szpieg w Stanach Zjednoczonych (ttumaczenie $z$ angielskiego), Zarząd II SG WP, Warszawa 1962 [resortowe wydanie polskojęzyczne wspomnień Pawła Monata: P. Monat, J. Dille, Spy in the US, New York 1961].

26 AIPN, Zarząd II SG WP, 2602/16315, Wykaz oficerów ubyłych z Zarządu II Sztabu Generalnego, których zna ppłk Marian Kozłowski, [Warszawa] 21 X 1972 r., k. 150-163. Zob. także: AIPN, Wojskowa Prokuratura Okręgowa w Warszawie, 00299/1-3, Akta w sprawie 
przez kpt. Jerzego Sumińskiego w 1981 r. ${ }^{27}$, aż w końcu przez Marka Ostaszewicza oraz płk. Włodzimierza Ostaszewicza w $1981 \mathrm{r}^{28}$ Mimo pewności, że zarówno Monat, jak i Ostaszewicze znali go osobiście, a Sumiński zapoznawał się z jego aktami, wykorzystywany był dalej w służbie poza wojskiem. Zarówno wywiad, jak i kontrwywiad wojskowy Polski Ludowej posiadały informację, że wywiady tzw. krajów kapitalistycznych nie mają wiadomości o faktycznej roli Mazurka ${ }^{29}$. Pytanie, na ile te wiadomości były pewne przy tylu uciekinierach znających „Barcza”? Nie przeszkadzało to jednak wykorzystywać Mazurka do 1991 r. jako oficera pod przykryciem ${ }^{30}$. Mazurek przebywał na włoskiej placówce od 4 kwietnia 1982 r. do 30 czerwca 1987 r., kierując siatką agentów, informatorów i tzw. pracowników nielegalnego aparatu pomocniczego rezydentury. Do głównych jego zadań należało „śledzenie sytuacji wywiadowczej”31 oraz studiowanie

przeciwko ppłk. Marianowi Kozłowskiemu; AIPN, SWSW, 2386/15864-15868, Sprawa Operacyjnego Poszukiwania ps. „Milczek” dot. zaginionego agenta ppłk. Mariana Kozłowskiego.

27 AIPN, Zarząd II SG WP, 003419/1, Karta pracownika Zarządu II dot. ppłk. Franciszka Mazurka. Centrala Zarządu II SG WP uznała, że Sumiński nie znał osobiście Mazurka, a Mazurek o Sumińskim nigdy nie słyszał, więc nie doszło do dekonspiracji. Zob. AIPN, Zarząd II SG WP, 2602/27084, Analiza oficera poza wojskiem płk. Franciszka Mazurka, [Warszawa] 20 VII 1981 r., k. 146.

28 Marek Ostaszewicz (ur. 4 VI 1950 r. w Warszawie) pracownik Konsulatu Generalnego PRL w Kanadzie, współpracownik Zarządu II SG WP, syn płk. Włodzimierza Ostaszewicza (ur. 12 VII 1922 r. w Augustowie), po ucieczce ojca wyjechał wraz z żoną z Kanady do Stanów Zjednoczonych, gdzie pozostał na stałe. Pułkownik Włodzimierz Ostaszewicz był szefem Oddziału III wywiadu wojskowego w czasie, gdy pełnił w nim służbę Mazurek. Trzykrotnie go jeszcze później opiniował, kiedy już nie był jego bezpośrednim przełożonym. CAW, TAP, 1849/95/1472, Opinia służbowa, [Warszawa] 29 XII 1958 r., k. 43-43v. Na temat płk. Ostaszewicza i jego syna zob. S. Cenckiewicz, Długie ramię Moskwy..., s. 230 oraz 308309; AIPN, SWSW, 2386/16655, Sprawa Operacyjnego Poszukiwania krypt. „Uciekinier”; AIPN, Sąd WOW, 940/367-370, Akta śledztwa w sprawie dezercji i ucieczki za granicę płk. Włodzimierza Ostaszewicza; AIPN, Sąd WOW, 939/761, t. 1-2, Akta w sprawie Krystyny Kruczek-Ostaszewicz i Marka Ostaszewicza oskarżonych o zdradę ojczyzny; katalog IPN, https://katalog.bip.ipn.gov.pl/informacje/81620 (dostęp: 19 III 2018 r.).

29 AIPN, SWSW, 2386/34655, Pismo szefa WSW, gen. Edwarda Poradki do szefa Zarządu II SG WP, gen. Romana Misztala, [Warszawa] 7 I 1983 r., k. 7-10.

30 Franciszek Mazurek dalej był „aktywnie wykorzystywany do zabezpieczenia bieżących potrzeb Centrali”. Cyt. AIPN, Zarząd II SG WP, 2602/26657, Analiza stanu osobowego aparatu wywiadowczego i kandydatów pozostających w zainteresowaniu, b.m. 1 XI 1990 r., k. 335.

31 Sytuacja wywiadowcza to całokształt czynników ułatwiających bądź utrudniających prowadzenie działalności wywiadowczej na terytorium obcego państwa. Czynniki takie mogą mieć miejsce ze względu na ustrój, prowadzoną politykę wewnętrzną i zagraniczną, położenie geograficzne, historię, zwyczaje, kulturę oraz sytuację kontrwywiadowczą. Sytuacja wywiadowcza może być rozpatrywana w stosunku do określonego obszaru geograficznego (państwa, regionu, miasta, dzielnicy) lub pojedynczego obiektu w zależności od konkretnych potrzeb centrali wywiadu wojskowego. Zob. AIPN, Biblioteka byłych wojskowych organów bezpieczeństwa państwa polskiego, 2603/13788, Terminologia wywiadowcza (tymczasowa), 
„sytuacji wojskowo-politycznej” we Włoszech, czyli zbieranie wszelkich wiadomości o potencjale zbrojeniowym, technice wojskowej i rozwoju armii włoskiej ${ }^{32}$. Mazurek miał za zadanie także „naprowadzać” (tzw. praca typowniczo-werbunkowa) kandydatów na agentów i organizować miejsca spotkań $^{33}$.

Dodatkowo „Barcz” dostawał z centrali wywiadu wojskowego zadania specjalne, jak skoncentrowanie swojej uwagi na "kontaktach ze środowiskiem kościelno-watykańskim” czy „ustalenia ośrodków dywersji ideologicznej" ${ }^{34}$. Według oceny Zarządu II SG WP z tych zadań wywiązywał się dobrze, przekazując ok. 200 informacji rezydentowi, który w formie depesz przesyłał je centrali wywiadu. Ponieważ oficjalnie Mazurek występował pod szyldem PLL „LOT”, znacznie swobodniej mógł wchodzić w środowisko kościelne i je penetrować. Dodatkowo próbował pomagać w przesyłaniu paczek pomocowych do kraju, co ułatwiało mu nawiązywanie kontaktów z polskimi duchownymi pracującymi w Watykanie. Aktywność ta nie spodobała się jednak jego przełożonym z centrali wywiadu wojskowego ${ }^{35}$.

Według „Oceny pracy” centrali peerelowskiego wywiadu wojskowego do najciekawszych osób, z którymi „Barcz” się spotykał, należały ${ }^{36}$ :

- ks. prałat Ryszard Karpiński - ówczesny pracownik Komisji ds. Migracji i Turystyki. Księdza Karpińskiego polecił osobiście sam abp. Bronisław Dąbrowski. Miał wprowadzić płk. Mazurka w „swoje środowisko”. Po powrocie do kraju nadal podtrzymywał z oficerem znajomość;

Zarząd II SG WP, Warszawa 1970, s. 25-26; W. Bagieński, Dwa słowniki wywiadu wojskowego..., s. 724.

32 AIPN, Zarząd II SG WP, 2602/27084, Rozkaz specjalny dla pracownika rezydentury płk. Franciszka Mazurka ps. „Barcz” rezydentury rzymskiej, [Warszawa] 2 I 1982 r., k. 168-170. „Barcz” wykorzystywał do realizacji tematyki wojskowej i lotniczej dwa źródła „Max” lub „Maks” (Massini - informator nieświadomy - sprawa prowadzona na rzecz Oddziału „Y” [agenturalnego], w 1987 r. zwerbowany ostatecznie przez płk. Wita Łączyńskiego) i „Lem” (Luigi Mezza - informator nieświadomy, zrezygnowano z niego na przełomie 1986/1987 r.). AIPN, Zarząd II SG WP, 2602/27084, Ocena pracy płk. Franciszka Mazurka, pseudonim „Barcz” za okres pobytu na placówce w Rzymie w okresie 4 I 1982 - 30 VI 1987, Warszawa 4 IX 1987 r., k. 22.

33 W 1985 r. „Barcz” zorganizował np. miejsce spotkań krypt. „Panorama”. Zob. AIPN, Zarząd II SG WP, 2602/16610, Pismo nr 10/85, [Warszawa] 30 IX 1985 r., k. 330.

34 Cyt. AIPN, Zarząd II SG WP, 2602/27084, Załącznik 6 do pisma nr 4/82, [Warszawa] 26 III 1982 r., k. 158. Zob. także: AIPN, Zarząd II SG WP, 2602/16173, Pismo nr 1/82, [Rzym] 8 I 1982 r., k. 1.

35 AIPN, Zarząd II SG WP, 2602/27084, Parafraza szyfrogramu do Rzymu, 16 III 1982 r., k. 157. Zob. także AIPN, Zarząd II SG WP, 2602/27084, Notatka służbowa dot. przesyłek kierowanych do kraju drogą lotniczą w ramach akcji pomocy, [Rzym kwiecień 1982 r.], k. 153-156.

36 AIPN, Zarząd II SG WP, 2602/27084, Zadania wywiadowcze dla „Barcza” do realizacji w 1982 r., [Warszawa] 24 II 1982 r., k. 159-161. 
- ks. prałat Sławoj Leszek Głódż ${ }^{37}$ - pracownik Kongregacji ds. Kościołów Wschodnich. Przedstawiany był jako reprezentant młodych księży „o zacięciu politycznym”. „Kontakt przekazany następcy”38;

- ks. Marian Burniak - proboszcz parafii polskiej pw. św. Stanisława w Rzymie;

- Stanisław (imię zakonne Konrad) Hejmo ${ }^{39}$ - dyrektor Domu Pielgrzyma Polskiego w Rzymie, z racji pełnienia swojej funkcji wszedł do „polskiej elity kościelnej w Rzymie". Posiadał liczne kontakty w sekretariacie

37 Biskup Sławoj Leszek Głódź (w aktach wywiadu wojskowego występuje jako ks. Sławomir Głodź) (ur. 13 VIII 1945 r. w Bobrówce) święcenia prezbiteratu przyjął w 1970 r., doktor prawa kanonicznego, pracownik watykańskiej Kongregacji ds. Kościołów Wschodnich w latach 1981-1991 (sekcja Kościoła obrządku bizantyjsko-ukraińskiego oraz sekcja Kościoła na Białorusi obrządku bizantyjsko-ruteńskiego), biskup polowy Wojska Polskiego w latach 1991-2004, biskup diecezjalny warszawsko-praski w latach 2004-2008, arcybiskup metropolita gdański od 2008 r. W dniu 21 I 1991 r. wraz z ustanowieniem Ordynariatu Polowego w Polsce został mianowany przez Jana Pawła II biskupem polowym Wojska Polskiego z siedzibą tytularną w Bettonie we Włoszech. Awansowany 18 IV 1991 r. przez Prezydenta RP, Lecha Wałęsę, na stopień generała brygady, a 11 XI 1993 r. na stopień generała dywizji. Zob. Arcybiskup Metropolita Sławoj Leszek Głódź, https://www.diecezja.gda.pl/archidiecezja/biskupi/arcybiskup-metropolita-gdanski-slawoj-leszek-glodz (dostęp: 19 III 2018 r.). Na temat inwigilacji przez służby PRL zob. katalog IPN, http://katalog.bip.ipn.gov.pl/informacje/116849 (dostęp: 19 III 2018 r.).

38 Cyt. AIPN, Zarząd II SG WP, 2602/27084, Ocena pracy płk. Franciszka Mazurka, pseudonim „Barcz” za okres pobytu na placówce w Rzymie w okresie 4 I 1982 - 30 VI 1987, Warszawa 4 IX 1987 r., k. 23. Następcą płk. Franciszka Mazurka był Jan Marek Mich, ps. „Cezar”. Zob. przyp. 69.

39 Ojciec Konrad Hejmo (w aktach wywiadu wojskowego występuje jako Stanisław Hejmo) (ur. 6 IV 1936 r. w Kostrzy). Dominikanin (śluby zakonne przyjął w 1953 r.), dyrektor Domu Pielgrzyma w Rzymie. Od 1964 r. zarejestrowany przez Wydział IV Komendy Milicji Obywatelskiej w Warszawie i rozpracowywany w ramach teczki ewidencji operacyjnej na księdza o nr 32390. W 1980 r. zarejestrowany przez Wydział V Departamentu IV MSW w charakterze tajnego współpracownika ps. „Dominik” o nr 47865. Zob. A. Grajewski, P. Machcewicz, J. Żaryn, Raport: Sprawa o. Konrada Hejmo. Działania Służby Bezpieczeństwa przeciwko Kościołowi katolickiemu w latach 1975-1988, bdw [Warszawa 2005]; J. Puciłowski OP, Portrety imienne i bezimienne. Polscy dominikanie a bezpieka 1945-1989, Kraków 2017, s. 72-73, 99-100, 183-184; P. Reina, Anatomia linczu. Sprawa Ojca Konrada Hejmo, Warszawa 2006, s. 5-76; AIPN, MSW, 02320/188 t. 1-5, Teczki personalne i pracy tajnego współpracownika/kontaktu operacyjnego ps. „Dominik”, „Hejnał”; AIPN, MSW, 003322/1, Karta o symbolu EOK-6/63 z kartoteki księży katolickich dot. Stanisława Hejmo; AIPN, MSW, 003322/1, Załącznik do karty o symbolu EOK-6/63 z kartoteki księży katolickich dot. Stanisława Hejmo; AIPN, MSW, 003322/1, Karta o symbolu EOK-6-A/63 z kartoteki księży katolickich dot. Stanisława Hejmo; AIPN, MSW, 2911/1, Karta o symbolu EO-4/77 z kartoteki ogólnoinformacyjnej dot. Stanisława Hejmo; AIPN, MSW, 2911/1, Karta o symbolu EO-4-A/77 z kartoteki ogólnoinformacyjnej dot. Stanisława Hejmo; AIPN, MSW, 2912/1, Karta o symbolu EO-6-A z kartoteki ogólnoinformacyjnej dot. Stanisława Hejmo; AIPN Po, WUSW w Poznaniu, 0044/1, Karta o symbolu EO-4-A/74 z kartoteki ogólnoinformacyjnej dot. Stanisława Hejmo. 
papieskim i w sekretariacie stanu Watykanu. „Kontakt został przekazany następcy"

- ks. Jan Piekarski ${ }^{41}$ - prowincjał Zgromadzenia Redemptorystów w Rzymie;

- ks. dr Jan Kupka ${ }^{42}$ - prowincjał Stowarzyszenia Pallotynów w Rzymie. Mazurek, przebywając we Włoszech, najpierw był w łączności z rezydentem „Rafałem” - kmdr. por. Czesławem Wawrzyniakiem, następnie, od 1983 r., z rezydentem „Remo” - ppłk. Witem Łączyńskim ${ }^{43}$. Kontaktował się

40 Cyt. AIPN, Zarząd II SG WP, 2602/27084, Ocena pracy płk. Franciszka Mazurka, pseudonim „Barcz” za okres pobytu na placówce w Rzymie w okresie 4 I 1982 - 30 VI 1987, Warszawa 4 IX 1987 r., k. 23. Także przekazany współpracownikowi ps. „Cezar”.

${ }_{41}$ Ksiądz Jan Gerard Piekarski (w aktach wywiadu wojskowego występuje jako Gerard Jan Piekarski) (ur. 16 X 1924 r. w Krakowie - zm. 22 X 2012 r. w Warszawie). Redemptorysta (profesję zakonną założył w 1941 r., święcenia kapłańskie przyjął w 1949 r.), w latach 1971-2007 pełnił funkcję prokuratora misji zagranicznych, wicerektora i ekonoma domu generalnego w Rzymie, był również w tym czasie duszpasterzem sióstr zakonnych oraz przewodnikiem i opiekunem pielgrzymów. Zarejestrowany przez Wydział III Departamentu IV MSW i rozpracowywany w ramach teczki ewidencji operacyjnej na księdza o nr 31076. Materiały o sygn. 54010/II zakończono w 1987 r. i złożono do archiwum Biura „C” MSW. Zob. AIPN, MSW, 0222/640, Piekarski Jan Gerard; AIPN, SUSW w Warszawie, 419/1, Karta o symbolu EOK-6-A/63 z kartoteki ogólnoinformacyjnej dot. Jana Piekarskiego; AIPN, MSW, 2911/1, Karta o symbolu Mkr-2 z kartoteki ogólnoinformacyjnej dot. Jana Piekarskiego; AIPN, MSW, 2911/1, Karta o symbolu EO-4/62 z kartoteki ogólnoinformacyjnej dot. Jana Piekarskiego; AIPN, MSW, 2911/1, Karta o symbolu EO-4/62 z kartoteki ogólnoinformacyjnej dot. Jana Piekarskiego; AIPN, MSW, 2911/2, Karta o symbolu E-14 z kartoteki odtworzeniowej dot. Jana Piekarskiego.

42 Ks. Jan Kupka (ur. 12 I 1950 r. w Nieskurzowie Nowym). Pallotyn (święcenia przyjął w 1975 r.), od 1977 r. w Wiedniu na studiach (doktorat z teologii pastoralnej), od 1981 r. pracował w Zarządzie Generalnym Stowarzyszenia Apostolstwa Katolickiego w Rzymie. W latach 1969-1982 rozpracowywany przez SB w ramach teczki ewidencji operacyjnej na księdza o nr 37255. W 1989 r. zarejestrowany przez Wydział III Departamentu I MSW jako figurant w ramach Segregatora Materiałów Wstępnych krypt. „Taruk” o nr 1097. AIPN, MSW, 02071/50, Kupka Jan; AIPN, MSW, 003322/1, Karta o symbolu EOK-6/63 z kartoteki księży katolickich dot. Jana Kupki; AIPN, MSW, 003322/1, Załącznik do karty o symbolu EOK-6/63 z kartoteki księży katolickich dot. Jana Kupki; AIPN, MSW, 1437/2, Karta o symbolu E-59 z kartoteki księży katolickich dot. Jana Kupki; AIPN, MSW, 2911/1, Karta o symbolu EO-4-A/77 z kartoteki ogólnoinformacyjnej dot. Jana Kupki; AIPN, MSW, 2911/2, Karta o symbolu E-14 z kartoteki odtworzeniowej dot. Jana Kupki.

43 Podpułkownik Wit Lech Łączyński (ur. 11 VI 1941 r. w Warszawie). Członek PZPR od 1968 r. Od 19 X 1962 r. w Siłach Zbrojnych PRL, słuchacz Wojskowej Akademii Technicznej (WAT), od 1968 r. pracownik wywiadu wojskowego. W 1980 r. ukończył studia Akademii Spraw Wewnętrznych w Warszawie. Absolwent kursu dla kadry kierowniczej przy Akademii MON w ZSRS. Attaché wojskowy w Rzymie w latach 1983-1987, wcześniej attaché wojskowy na Kubie w latach 1972-1975. Występował pod nazwiskiem legalizacyjnym Leszek Michalewicz i pod pseudonimami „Remo”, „Lechita” oraz „Gabriel”. Od 1987 r. pełnił obowiązki zastępcy komendanta ds. szkolenia w Centrum Szkolenia Wojskowej Służby Zagranicznej Zarządu II SG WP. W 1990 r. najpierw został zastępcą szefa Oddziału „P” (krajów pozaeuropejskich), a następnie Oddziału "A” (agenturalnego wywiadu operacyjnego) Zarządu II SG 
z nim również mjr Zdzisław Żyłowski ps. „Jacek”44, zastępca attaché (jednocześnie zastępca rezydenta), następnie mjr Jan Oczkowski, ps. „Saturn”, od 1984 r. zastępca attaché (jednocześnie zastępca rezydenta) ${ }^{45}$, a od 1986 r.

WP. Od 1991 r. zastępca, a następnie szef Oddziału 3 Zarządu II Szefostwa/Departamentu Wojskowych Służb Informacyjnych. W latach 1995-1999 attaché wojskowy w Chorwacji. W 1999 r. przeszedł do rezerwy w stopniu pułkownika. Znany z akt i osobiście kpt. Jerzemu Sumińskiemu. WSW założyła na niego materiały wstępne krypt. „Nerwus” ze względu na podejrzenie zagubienie dokumentu niejawnego. Autor podręcznika „Prowadzenie pracy wywiadowczej z pozycji attachatu wojskowego", Warszawa 1989 (AIPN, Biblioteka byłych wojskowych organów bezpieczeństwa państwa polskiego, 03177/64, t. 1). Zob. CAW, TAP, 1921/03/391, Akta personalne Wita Łączyńskiego; AIPN, Zarząd II SG WP, 2602/24981, Akta personalne Wita Łączyńskiego; AIPN, Zarząd II SG WP, 2602/23969, Akta personalne pomocnicze Wita Łączyńskiego; AIPN, SWSW, 2386/32332, Teczka personalna Wit Łączyński, Włochy; AIPN, Zarząd II SG WP, 003419/1, Karta pracownika Zarządu II dot. mjr. Łączyńskiego.

44 Major Zdzisław Żyłowski (ur. 18 X 1940 r. w Krakowie). Członek PZPR od 1962 r. Od 25 IX 1959 r. w Siłach Zbrojnych PRL, służba w wojskach zmechanizowanych, od 1966 r. pracownik wywiadu wojskowego, w latach 1969-1972 oficer do zleceń attachatu w Rzymie (w okresie 1970-1972 prowadził rezydenturę „Góra”), a w latach 1979-1984 zastępca attaché w Rzymie, od 1984 r. pełnił służbę w Oddziale „Y” (agenturalnym) Zarządu II SG WP (od 1989 r. szef tegoż oddziału). Występował pod nazwiskiem legalizacyjnym Kurowski i pod pseudonimem „Jacek”. Był znany Marianowi Kozłowskiemu jako oficer Zarządu II SG WP. Bardzo dobrze oceniany przez WSW (w Rzymie wykonywał też zadania dla kontrwywiadu wojskowego). Służbę w wywiadzie pełnił po $1990 \mathrm{r}$. Brak informacji o dacie odejścia z wojska. Zob. AIPN, Zarząd II SG WP, 3332/3, Akta personalne Zdzisława Żyłowskiego; AIPN, Zarząd II SG WP, 2602/21746, Akta personalne pomocnicze Zdzisława Żyłowskiego; AIPN, SWSW, 2386/32559, Akta personalne dot. Żyłowskiego; AIPN, Zarząd II SG WP, 2602/ 24850, Dokumentacja dot. Zdzisława Żyłowskiego; AIPN, Zarząd II SG WP, 2602/28307, Teczka pracy „Jacek”; AIPN, Zarząd II SG WP, 003419/1, Karta pracownika Zarządu II dot. Żyłowskiego; katalog IPN, https://katalog.bip. ipn.gov.pl/informacje/103957 (dostęp: 19 III 2018 r.).

45 Major Jan Oczkowski (ur. 21 VIII 1946 r. w Krakowie). Członek PZPR od 1968 r. Od 28 IX 1964 r. w Siłach Zbrojnych PRL, służba w wojskach pancernych, od 1979 r. pracownik wywiadu wojskowego. Zastępca attaché w Rzymie w latach 1984-1986, zastąpił mjr. Żyłowskiego, wcześniej pracował na kierunku francuskim. Od 1986 r. starszy oficer Wydziału 2 Agenturalnego Wywiadu Operacyjnego w Gdyni, następnie Oddziału „K” (krajów europejskich). Od 1987 r. pełnił obowiązki szefa Wydziału 3 Agenturalnego Wywiadu Operacyjnego w Szczecinie, następnie wrócił do Oddziału „K” (krajów europejskich). Od 1990 r. starszy specjalista Wydziału 12. Występował pod nazwiskiem legalizacyjnym Jan Niemczewski. Znany z akt i osobiście kpt. Jerzemu Sumińskiemu - byli razem na kursie specjalnym w Ośrodku Szkolenia Zarządu II SG WP. Prawdopodobnie osoba zaufana WSW występująca jako Jan „O”. Służbę w wywiadzie pełnił po 1990 r. Brak informacji o dacie ubycia z wojska. Zob. AIPN, Wojskowa Komisja Uzupełnień (dalej: WKU) Warszawa-Praga, 2554/139, Akta personalne Jana Oczkowskiego; AIPN, Zarząd II SG WP, 2602/23964, Akta personalne pomocnicze Jana Oczkowskiego; AIPN, Zarząd II SG WP, 2602/24789, Akta personalne Jana Oczkowskiego; AIPN, Zarząd II SG WP, 2602/23050, Teczka personalna Oczkowski „Saturn”; AIPN, Zarząd II SG WP, 003419/1, Karta pracownika Zarządu II dot. Oczkowskiego; AIPN, SWSW, 2386/32332, Notatka służbowa z rozmowy z OZ ppłk. Janem „O”, 17 V 1986 r., k. 62-63; katalog IPN, https://katalog.bip.ipn. gov.pl/informacje/68148 (dostęp: 19 III 2018 r.). 
ppłk Jerzy Kobacki, ps. „Taurus”46. Kiedy płk Mazurek miał wracać do kraju, nowym attaché $e^{47}$ w Rzymie został ppłk Roman Oziębała, ps. „Maxime”48. Mazurek spotykał się z pracownikami attachatu także po linii politycznej, był członkiem egzekutywy partyjnej w ambasadzie PRL ${ }^{49}$.

Mazurek, zostając pracownikiem rezydentury rzymskiej, nie miał przekazanych na łączność żadnych informatorów związanych z Kościołem katolickim. Jego zadania miały być stricte wywiadowcze i typowniczo-werbunkowe. Główne pole zainteresowania to włoskie siły powietrzne (służba kontroli powietrznej kraju, młodzi oficerowie rezerwy, służby łączności i telekomunikacji). Miał do tego wykorzystać stanowisko, jakie oficjalnie piastował. Przykrycie miało także służyć do ewentualnego wskazywania emisariuszy „Solidarności” kontaktujących się z Watykanem i wykrywanie na terenie państwa kościelnego środowiska „dywersji ideologicznych” współpracujących z polską opozycją ${ }^{50}$. W pierwszym okresie swojego pobytu nawiązał

46 Podpułkownik Jerzy Kobacki (ur. 20 V 1948 r. w Tomaszowie Mazowieckim). Członek PZPR od 1969 r. Od 1966 r. w Siłach Zbrojnych PRL, od 1975 r. pracownik wywiadu wojskowego. Najpierw jako starszy projektant Oddziału XXVIII (informatyki), później oficer Oddziału IV (anglo-amerykański), następnie Oddziału „K” (krajów europejskich). Wielokrotnie odbywał służbę poza wojskiem, dwukrotnie pełnił też służbę w ramach Polskiego Kontyngentu Wojskowego w Siłach Zbrojnych ONZ w Syrii. Na placówce w Rzymie od 28 VIII 1986 r. jako zastępca attaché przy ambasadzie PRL w Rzymie (do 15 X 1988 r.). Używał pseudonimu „Taurus”. Od 1 XII 1988 r. na etacie starszego wykładowcy cyklu szkolenia operacyjnego w Centrum Szkolenia Wojskowej Służby Zagranicznej. Służbę w wywiadzie pełnił po 1990 r. Brak informacji o dacie odejścia z wojska. Zob. AIPN, WKU Warszawa-Praga, 2554/162, Akta personalne Jerzego Kobackiego; AIPN, Zarząd II SG WP, 2602/22759, Teczka personalna „Taurus” 1966[-1990]; AIPN, Zarząd II SG WP, 2602/24440, Dokumenty personalne - Kobacki Jerzy; katalog IPN [protokół on-line] https://katalog.bip.ipn.gov.pl/informacje/67873 (dostęp: 19 III 2018 r.).

47 Od 2 IV 1987 r. zob. AIPN, Zarząd II SG WP, 2602/27916, Zeszyt kierunkowy - Włochy, k. 27.

48 Podpułkownik Roman Oziębała (ur. 9 VIII 1948 r. w Środzie Śląskiej). Członek PZPR od 1967 r. W Siłach Zbrojnych PRL od 1965 r., od 1968 r. w wywiadzie wojskowym. Najpierw w Węźle Łączności w Janówku, następnie w 2 Pułku Rozpoznania Radioelektronicznego w Przasnyszu. W latach 1971-1975 słuchacz WAT. Od 1982 r. w Oddziale VII (rozpoznania radioelektronicznego), następnie Oddziale „A” (Agenturalnego Wywiadu Operacyjnego) Zarządu II SG WP, a w latach 1987-1990 attaché w Rzymie. Używał pseudonimu „Maxime”. Przed wyjazdem do Włoch trafił w 1986 r. na półroczny staż do attachatu w Paryżu. Służbę w wywiadzie pełnił po $1990 \mathrm{r}$. Brak informacji o dacie odejścia z wojska. Zob. AIPN, Zarząd II SG WP, 2602/24287, Dokumenty personalna - Oziębała Roman; AIPN, Zarząd II SG WP, 2602/27571, Teczka „Maxime”, 1986-1990; katalog IPN, https://katalog.bip.ipn.gov.pl/informacje/73703 (dostęp: 19 III 2018 r.).

49 AIPN, Zarząd II SG WP, 2602/27152, Załącznik nr 7 do pisma 5/84, [Rzym] $17 \mathrm{~V}$ 1984 r., k. 204-205.

50 AIPN, Zarząd II SG WP, 2602/27084, Załącznik nr 1 do rozkazu specjalnego dot. zadania wywiadowczego dla płk. Franciszka Mazurka, [Warszawa] 3 I 1982 r., k. 166. W czerwcu 
kontakty osobiste $\mathrm{z}$ abp. Bronisławem Dąbrowskim ${ }^{51}$, który w tym czasie pełnił funkcję sekretarza Episkopatu Polski. To spowodowało, że w okresie dwóch lat zdobył bezpośrednie kontakty z ponad dwudziestoosobową grupą złożoną z księży, zakonników oraz sióstr zakonnych. „Barcz” wyselekcjonował $\mathrm{z}$ tej grupy osoby mające najlepszy dostęp do informacji zarówno z kręgu watykańskiego, jak i z Episkopatu Polski w myśl zasady „Im więcej źródeł wykorzystuje się przy analizie jakiegoś faktu, tym większa jest gwarancja poprawnego ustalenia stopnia wiarygodności" ${ }^{2}$. Osoby te dzieliły się z nim informacjami „W sposób mniej lub bardziej świadomy (część w sposób zupełnie nieświadomy)" ${ }^{\prime 3}$. Sam abp Dąbrowski w swoich relacjach przekazanych Peterowi Rainie nie wspomina Franciszka Mazurka ${ }^{54}$, chociaż spotkań tych miał z nim odbyć wiele.

Już na początku swojej działalności wywiadowczej w Rzymie Mazurek nawiązał dobre kontakty z księżmi z Polski przebywającymi w Watykanie, zaliczanymi przez wywiad wojskowy do tzw. środowiska watykańskiego.

1984 r. attaché Łączyński dostał od attachatu sowieckiego w ramach wymiany materiały dot. "Solidarności”, m.in. Bogdana Lisa i Andrzeja Chodakowskiego, zob. AIPN, Zarząd II SG WP, 2602/16610, Szyfrogram płk. Wita Łączyńskiego z Rzymu, 13 VI 1984 r., k. 94. Sam „Barcz” doniósł na grupę studentów z Krakowa, która pod koniec listopada 1985 r. przybyła do Rzymu i na audiencji u papieża większość z nich miała przypięte znaczki „Solidarności”. Zob. AIPN, Zarząd II SG WP, 2602/16610, Pismo wychodzące Pf 2316/POK/85, Rzym 27 XII 1985 r., k. 368.

51 Arcybiskup Bronisław Wacław Dąbrowski (ur. 2 XI 1917 r. w Grodźcu, zm. 25 XII 1997 r. w Warszawie). Orionista (święcenia kapłańskie przyjął w 1945 r.), w latach 1962-1993 biskup pomocniczy warszawski, w latach 1969-1993 sekretarz generalny Konferencji Episkopatu Polski, od 1982 r. arcybiskup tytularny pro hac vice, w latach 1993-1997 biskup senior archidiecezji warszawskiej. W 1989 r. brał udział w rozmowach władz państwowych PRL z przedstawicielami opozycji solidarnościowej w Ośrodku Konferencyjnym MSW w Magdalence oraz w obradach Okrągłego Stołu. AIPN, MSW, 1437/2, Karta o symbolu E-59 z kartoteki księży katolickich dot. Bronisława Dąbrowskiego; AIPN, MSW, 003322/1, Karta o symbolu EOK-6/63 z kartoteki księży katolickich dot. Bronisława Dąbrowskiego; AIPN, MSW, 003322/1, Załącznik do karty o symbolu EOK-6/63 z kartoteki księży katolickich dot. Bronisława Dąbrowskiego; AIPN, MSW, 003322/1, Karta o symbolu E-16 z kartoteki księży katolickich dot. Bronisława Dąbrowskiego; AIPN, MSW, 2912/1, Karta o symbolu EOK-6-A z kartoteki odtworzeniowej dot. Bronisława Dąbrowskiego.

52 Cyt. AIPN, Biblioteka byłych wojskowych organów bezpieczeństwa państwa polskiego, 2603/13350, Praca informacyjna rezydentur, OS ZII SG WP, Warszawa 1977, s. 19.

53 Cyt. AIPN, Zarząd II SG WP, 2602/27084, Sprawozdanie pracownika rezydentury płk. Franciszka Mazurka „Barcza” z pracy za granicą we Włoszech za okres od 4 I 1982 r. do 30 VI 1987, [Warszawa] 17 VIII 1987 r., k. 27-33. Zaraz po przyjeździe „Barcza” do Włoch, kiedy w okresie aklimatyzacji miał uczyć się języka włoskiego, był już dobrze oceniany przez centralę wywiadu wojskowego za kontakty „kościelno-watykańskie”. Zob. AIPN, Zarząd II SG WP, 2602/27084, Załącznik 6 do pisma nr 4/82 dot. kontaktów „Barcza”, [Warszawa] 26 III 1982 r., k. 158; AIPN, Zarząd II SG WP, 2601/16173, Pismo nr 9, [Warszawa] 9 VII 1982 r., k. 61.

54 P. Raina, Arcybiskup Dąbrowski - rozmowy watykańskie, Warszawa 2001, s. 237-258. 
Przede wszystkim rozmawiał z bp. Bronisławem Dąbrowskim i bp. Julianem Groblickim ${ }^{55}$. Z rozmów tych wynikało, że Kościół katolicki w Polsce ma duże zastrzeżenia do działalności „Solidarności”, m.in. miał razić antyklerykalny charakter Konfederacji Polski Niepodległej i Komitetu Obrony Robotników (KOR) oraz tzw. względy syjonistyczne (żydowskie pochodzenie części środowiska opozycyjnego). Dodatkowo zachodziła obawa co do rzekomych przywilejów Kościoła katolickiego podczas stanu wojennego, co mogło wywołać falę oburzenia w społeczeństwie. Księża, z którymi spotykał się „Barcz”, uważali także, że za zamachem na papieża nie stał islam, a loże masońskie. Te informacje i chęć współpracy z przedstawicielem Lotu od razu zostały przez rezydenturę przesłane do centrali wywiadu wojskowego ${ }^{56}$. Wobec sukcesów „Barcza” centrala wywiadu w 1983 r. oprócz zadań typowo wywiadowczych zaplanowała dla niego także wytypowanie ks. Lorka na informatora i stałe utrzymywanie kontaktów z księżmi Ryszardem Karpińskim, Janem Piekarskim, Henrykiem Kietlińskim i Ksawerym Sokołowskim ${ }^{57}$. W połowie 1983 r. kierownictwo centrali Zarządu II SG

55 Biskup Julian Jan Groblicki (ur. 14 XII 1908 r. w Bieżanowie - zm. 4 V 1995 r. w Zakopanem), święcenia prezbiteratu przyjął w 1933 r. Kapelan i sekretarz osobisty abp. Adama S. Sapiehy w latach 1936-1945, biskup sufragan archidiecezji krakowskiej w latach 19601992, następnie biskup senior tejże archidiecezji. Prowadzono wobec niego sprawę operacyjną, materiały o sygn. 10048/II już w 1967 r. złożono do archiwum Wydziału „C” KW MO w Krakowie. W 1989 r. akta zostały zniszczone. AIPN, MSW, 2911/1, Karta o symbolu E-14 z kartoteki ogólnoinformacyjnej dot. Juliana Groblickiego; Archiwum Instytutu Pamięci Narodowej w Krakowie (dalej: AIPN Kr), Wojewódzki Urząd Spraw Wewnętrznych (dalej: WUSW) w Krakowie, 00142/1, Karta o symbolu E-14-B z kartoteki ogólnoinformacyjnej dot. Juliana Groblickiego; AIPN Kr, WUSW w Krakowie, 00142/1, Karta o symbolu Mkr-3 z kartoteki ogólnoinformacyjnej dot. Juliana Groblickiego.

56 AIPN, Zarząd II SG WP, 2602/27084, Notatka służbowa „Barcza”, [Warszawa maj 1982 r.], k. $151-152$.

57 AIPN, Zarząd II SG WP, 2602/27084, Zadania „Barcza” na 1983 rok, [Warszawa] b.d., k. 131134. „Barcz” zapoznał się w tym czasie z aktami konsularnymi na osoby, które właśnie rozpracowywał (Jana Kupkę, Jana Gerarda Piekarskiego, Krzysztofa Koneckiego, Ryszarda Karpińskiego oraz Władysława Biedrzyckiego). Zob. AIPN, Zarząd II SG WP, 2602/16173, Załącznik nr 4 do pisma 1/83, [Rzym] 21 I 1983 r., k. 159. Dodatkowo rozpracowywał jako kandydatów na informatorów Henryka Kietlińskiego i Ksawerego Sokołowskiego. Zob. AIPN, Zarząd II SG WP, 2602/27084, Pismo 2/83, [Warszawa] 11 II 1983 r., k. 165. Ksiądz Franciszek Ksawery Sokołowski (ur. 3 XII 1939 r. w Osjakowie - zm. 17 VIII 2015 r. w Częstochowie) święcenia kapłańskie przyjął w 1962 r. W latach 1965-1968 kapelan bp. Stefana Bareły, w latach 1968-1972 studiował na Uniwersytecie Gregoriańskim w Rzymie, w latach 1972-1979 dyrektor Wydziału Duszpasterstwa Kurii Diecezjalnej w Częstochowie. Od 1979 r. oddelegowany do Rzymu, gdzie współorganizował, a później administrował Ośrodkiem dla Pielgrzymów Polskich „Corda Cordi”, a następnie Domem Polskim Jana Pawła II. Założył przy nim Ośrodek Dokumentacji Pontyfikatu Jana Pawła II oraz rozpoczął wydawanie miesięcznika „Kronika Rzymska”, którego był redaktorem. W 1981 r. został kapelanem papieża. Od 1985 r. skierowany do Francji, a następnie do Szwajcarii jako duszpasterz Polonii. Po powrocie do kraju kierował archidiecezjalną „Caritas” w Częstochowie. W latach 1963-1968 
WP zaproponowało rozpracowanie ks. Głodzia jako informatora „z zakresu tematyki watykańskiej”. Z tego względu nakazano „Barczowi” przejść do kontaktów nieoficjalnych $\mathrm{z}$ dala od Watykanu oraz uporządkować dane na temat niego i jego rodziny. Od samego ks. Głodzia Mazurek miał przede wszystkim spróbować uzyskać informację dot. „grup nacisków” w Watykanie, ich składu narodowościowego i międzynarodowych powiązań ${ }^{58}$. „Barcz” podkreślał, że z kontaktów służbowych czy czysto roboczych z niektórymi księżmi przechodzi na stopę towarzyską, co pozwala mu na „pełniejszą penetrację środowiska i dopływ interesujących informacji”" ${ }^{59}$. Między innymi

figurant Sprawy Operacyjnego Sprawdzenia prowadzonej przez KM MO/KP MO w Częstochowie oraz KW MO w Katowicach. Od 1968 r. zarejestrowany przez Wydział IV KW MO w Katowicach w charakterze tajnego współpracownika ps. „Janusz” o nr 15006, a następnie przerejestrowany w 1975 r. przez Wydział IV KW MO w Częstochowie w charakterze tajnego współpracownika ps. „Karol” o nr 369. W 1980 r. zakończono prowadzenie materiałów i złożono do archiwum Wydziału „C” KW MO w Częstochowie. W 1988 r. zarejestrowany przez Wydział III Departamentu I MSW w ramach zabezpieczenia operacyjnego (brak charakteru rejestracji) o nr 108883. Zob. AIPN Ka, WUSW w Częstochowie, 00142/102/J, Teczka personalna TW ps. „Janusz”, „Karol” dot. Sokołowskiego Franciszka Ksawerego; AIPN Ka, WUSW w Katowicach, 04/4066, Sprawa Operacyjnego Sprawdzenia dot. Sokołowskiego Franciszka Ksawerego; AIPN, MSW, 2911/1, Karta o symbolu Mkr-2 z kartoteki ogólnoinformacyjnej dot. Franciszka Sokołowskiego; AIPN, MSW, 2912/1, Karta o symbolu EO-4/77 z kartoteki odtworzeniowej dot. Franciszka Sokołowskiego; AIPN, MSW, 2912/1, Karta o symbolu EO-4-A/77 z kartoteki odtworzeniowej dot. Franciszka Sokołowskiego; AIPN, MSW, 2912/1, Karta o symbolu Mkr-2 z kartoteki odtworzeniowej dot. Franciszka Sokołowskiego; AIPN, MSW, 2912/1, Karta o symbolu E-16 z kartoteki odtworzeniowej dot. Franciszka Sokołowskiego; Archiwum Instytutu Pamięci Narodowej w Katowicach (dalej: AIPN Ka), WUSW w Katowicach, 00185/1, Karta o symbolu E-14 z kartoteki ogólnoinformacyjnej dot. Franciszka Sokołowskiego; AIPN Ka, WUSW w Częstochowie, 00185/3, Karta bez symbolu z kartoteki ogólnoinformacyjnej dot. Franciszka Sokołowskiego; AIPN Ka, WUSW w Katowicach, 073/1, Karta o symbolu Mkr-2 z kartoteki odtworzeniowej dot. Franciszka Sokołowskiego.

58 AIPN, Zarząd II SG WP, 2602/27084, Załącznik nr 3 do pisma nr 8/83 dot. zadań dla „Barcza”, [Warszawa] 11 VIII 1983 r., k. 126-128; AIPN, Zarząd II SG WP, 2602/16610, Ocena realizacji zadań rezydentury w Rzymie, [Warszawa] 8 XII 1984 r., k. 177-178.

59 Cyt. AIPN, Zarząd II SG WP, 2602/27084, Załącznik nr 1 do pisma nr 8/83 dot. wstępnej charakterystyki polskiego środowiska duchownego na terenie Rzymu, [Rzym] 16 VIII 1983 r., k. 120. Spotkania półoficjalne odbywały się więc w kawiarniach i restauracjach czy internacie dla księży, oficjalne w biurze Mazurka lub w instytucjach kościelnych. Zob. AIPN, Zarząd II SG WP, 2602/27084, Sprawozdanie z pracy za okres I półrocza 1984 r., [Rzym 1984 r.], k. 87. Przykładowe rozliczenia $\mathrm{z}$ tych spotkań $\mathrm{z}$ funduszu dewizowego zob. AIPN, Zarząd II SG WP, 2602/10143, Oświadczenie „Barcza” z tytułu współpracy z B-12, [Rzym] 26 XI 1985 r., k. 404; Oświadczenie „Barcza” z tytułu spotkania z osobą na kontakcie z BA-10, [Rzym] 1 X 1985, k. 405; Oświadczenie „Barcza” z tytułu spotkania w lokalu restauracyjnym z B-10, 27 IV 1985 r., k. 407; AIPN, Zarząd II SG WP, 2602/20146, Oświadczenie „Barcza” z tytułu spotkania w lokalu z B-10, [Rzym] 19 II 1986 r., k. 269; Oświadczenie „Barcza” z tytułu spotkania w lokalu z B-12, 19 III 1986 r., k. 270; AIPN, Zarząd II SG WP, 2602/16627, Zestawienie rachunków za wydatki specjalne w okresie 21 IX do [Rzym] 18 X 1986 r., 18 X 1986 r., k. 264; Oświadczenie „Barcza” o spotkaniu z B-13 + 1, [Rzym] 4 VIII 1986 r., k. 289; Oświadczenie „Barcza” o spotkaniu z B-10, [Rzym] 8 X 1986 r., k. 290; Zestawienie rachunków za wydatki specjalne realizowane 
na podstawie spotkań z ks. Głodziem i ks. Sokołowskim powstała notatka o postrzeganiu przez Watykan kardynała Glempa i jego wypowiedzi dot. noworocznego orędzia i spotkania z gen. Jaruzelskim ${ }^{60}$.

Według oceny płk. Franciszka Mazurka na szczególną uwagę zasługiwały kontakty z następującymi duchownymi:

- ks. prałatem Ryszardem Karpińskim - „poza wielu informacjami praktycznymi (dostarczył mi aktualny wykaz obsady personalnej polskich księży w instytucjach kościelnych i watykańskich w Rzymie oraz watykański wewnętrzny katalog telefoniczny) naprowadzał mnie kolejno na coraz to nowe osoby ze środowiska kościelnego. Odegrał on zatem bardzo ważną rolę w pierwszym okresie mojego pobytu w Rzymie, zwłaszcza w zakresie rozpoznania środowiska watykańskiego i polskich wpływowych ośrodków kościelnych. Pomimo upływu 2 lat od czasu powrotu do kraju, ks. bp R[yszard K[arpiński] przy każdej okazji pobytu w Rzymie szukał ze mną kontaktu, a także ponawiał zaproszenie do złożenia mu wizyty w Lublinie"61;

- Kazimierzem Lorkiem ${ }^{62}$ - „Kontakt z nim nawiązałem już w pierwszym okresie mojego pobytu na placówce. Otrzymałem od niego szereg fragmentarycznych informacji ze środowiska kościelnego, a także wiele różnorakich często wartościowych pozycji wydawniczych przesyłanych na bieżąco do Centrali. Stosownie do wytycznych Centrali zaprzestałem informacyjnego kontaktowania się z zainteresowanym ze względu na równoległe aktywne zaangażowanie się w jego rozpracowanie służb specjalnych

w okresie od 15 XI do 10 XII 1986 r., [Rzym] 20 XI 1986 r. [sic!], k. 332; Oświadczenie „Barcza” o spotkaniu w lokalu z B-10, 27 XI 1986 r., k. 342. Natomiast wszelkie wyliczenia rachunków za te spotkania zob. T. Krzyżak, A. Gajcy, Armia PRL kontra Papież..., s. 7-8.

60 Szczególnie źle odebrane było w środowisku kościelnym przyjęcie przez Prymasa zaproszenia na obiad z gen. Jaruzelskim. AIPN, Zarząd II SG WP, 2602/27084, Notatka dot. informacji odnośnie spraw polskich, uzyskanych z kręgów fatykańskich [sic!] (głównie ks. Głodziem i ks. Sokołowskim), [Rzym] 14 I 1984 r., k. 104-105.

61 Cyt. AIPN, Zarząd II SG WP, 2602/27084, Sprawozdanie pracownika rezydentury płk. Franciszka Mazurka „Barcza” z pracy za granicą we Włoszech za okres od 4 I 1982 r. do 30 VI 1987, [Warszawa] 17 VIII 1987 r., k. 33.

62 Ksiądz Kazimierz Maria Lorek (ur. 28 VIII 1958 r. w Nowym Sączu), w latach osiemdziesiątych studiował teologię we Włoszech. Barnabita (przyjęty do Zgromadzenia Księży Świętego Pawła w 1989 r.), pierwszy proboszcz parafii pw. św. Antoniego Marii Zaccarii w Warszawie, założyciel „Domu Chleba” dla bezdomnych. W 1982 r. zarejestrowany przez Wydział III Departamentu I MSW w kategorii kontaktu operacyjnego ps. „Perłak” o nr 16534. Materiały zniszczono w 1990 r. AIPN, MSW, 2911/1, Karta o symbolu E-4-A/77 z kartoteki ogólnoinformacyjnej dot. Kazimierza Lorka; AIPN, MSW, 2912/1 Karta o symbolu E-4-A/77 z kartoteki odtworzeniowej dot. Kazimierza Lorka; AIPN, MSW, 01746/4, Postanowienie o zniszczeniu akt sprawy archiwalnej departamentu I MSW, Warszawa 18 I 1990 r., k. 862-863. 
MSW”63. Jednak po okresie dwuletniej przerwy „Barcz” ponownie nawiązał kontakt $\mathrm{z}$ ks. Lorkiem ${ }^{64}$;

- ks. prałatem Sławojem Leszkiem Głodziem - „zalicza się do grupy młodszych księży o zacięciu politycznym. W latach 1980-1981 związany był z białostocką organizacją «Solidarności», pełniąc w niej funkcję kapelana. Trudno mu przychodzi odejście od koncepcji solidarnościowych, pomimo dużej dozy realizmu w ocenie sytuacji politycznej w Polsce. Odznacza się analitycznym umysłem, studiuje na bieżąco polską prasę krajową i emigracyjną, robi opracowania religijno-polityczne dla radia watykańskiego, wygłasza kazania o zabarwieniu politycznym w polskich kościołach w Rzymie”. A dalej: „Ostrożnie i umiejętnie prowadzone z nim rozmowy pozwoliły mi na uzyskanie w latach 1983-1985 wielu cennych i wiarygodnych informacji, zwłaszcza w okresie II wizyty papieskiej w Polsce. Ks. S[ławoj] G[łódź] darzył mnie dużym zaufaniem, czego zresztą nie omieszkał podkreślić kilkakrotnie podczas spotkań dwustronnych. Odniosłem jednak wrażenie, że w okresie ostatnich 2 lat stał się w kontaktach jakby nieco ostrożniejszy i unikający przekazywania wręcz niektórych ważnych, często delikatnych informacji. Przekazywane za jego pośrednictwem specjalne pakiety kontrolne przeznaczone dla Centrali nie wykazały prób kontroli tych przesyłek. Być może moje wątpliwości nie są uzasadnione, a wynikają z porównań kontaktów i wagi uzyskanych informacji od innych księży-informatorów. Kontakt z ks. S[ławojem] G[łodziem] przekazałem mojemu następcy. Spotkanie w lokalu przebiegało bardzo dobrze, ks. S[ławoj] G[łódź] wdał się otwarcie $\mathrm{w}$ wymianę poglądów, dokonał oceny pierwszego etapu wizyty papieskiej w Polsce i zaakceptował wyraźnie mojego następcę w oparciu między innymi o moje wcześniejsze rekomendacje"65;

- ks. Marianem Burniakiem - „Z racji długotrwałego pobytu w Rzymie oraz wieloletniego sprawowania funkcji proboszcza polskich parafii we Włoszech posiada szerokie kontakty i znajomości w kręgach kościelnych i środowisku watykańskim”. A dalej: „Z ks. M[arianem] B[urniakiem] utrzymywałem bardzo sympatyczne kontakty, dzielił się ze mną posiadanymi informacjami, skarżył się na oschłe i sztywne postępowanie bp

63 Cyt. AIPN, Zarząd II SG WP, 2602/27084, Sprawozdanie pracownika rezydentury płk. Franciszka Mazurka „Barcza” z pracy za granicą we Włoszech za okres od 4 I 1982 r. do 30 VI 1987, [Warszawa] 17 VIII 1987 r., k. 33-34.

64 AIPN, Zarząd II SG WP, 2602/27084, Sprawozdanie z pracy za okres I półrocza 1985 r., [Rzym 1985 r.], k. 73.

65 Cyt. AIPN, Zarząd II SG WP, 2602/27084, Sprawozdanie pracownika rezydentury płk. Franciszka Mazurka „Barcza” z pracy za granicą we Włoszech za okres od 4 I 1982 r. do 30 VI 1987, [Warszawa] 17 VIII 1987 r., k. 34. 
S[zczepana] Wesołego ${ }^{66}$ wobec jego osoby. W związku z jego pobytem za granicą nie mogłem bezpośrednio przekazać tego kontaktu mojemu następcy. W dniu mojego odlotu do kraju zadzwonił do mnie na lotnisko z pozdrowieniami, ja telefonicznie przedstawiłem mu mojego następcę (który był przy mnie), rozmawiał z nim telefonicznie i umówił się na spotkanie zapoznawcze w biurze" ${ }^{37}$;

- Stanisławem Hejmo (imię zakonne Konrad) - „Nawiązałem z nim kontakt bezpośredni dopiero w 1985 r., pomimo że spotykałem go przypadkowo wcześniej. Wówczas jednak przejął on kierownictwo Domu Pielgrzyma i nawiązane $\mathrm{z}$ nim kontakty stały się niezwykle cenne. $\mathrm{Z}$ racji pełnionej funkcji wszedł on do polskiej elity kościelnej w Rzymie, ma codzienne kontakty robocze i oficjalne w sekretariacie papieskim, w sekretariacie stanu Watykanu oraz $\mathrm{w}$ innych komórkach i kościelnych ośrodkach dyspozycyjnych. Utrzymuje stałe kontakty osobiste oraz telefoniczne z kierownictwem Episkopatu Polski. Bierze udział w różnych spotkaniach (obiady, kolacje) z udziałem papieża, organizuje audiencje generalne papieża w Watykanie i siedzibie letniej Castel Gandolfo, a także wszelkie dodatkowe spotkania polskie z papieżem”. A dalej: „Ks. $\mathrm{S}$ [tanisław] $\mathrm{H}$ [ejmo] okazał się bardzo cennym informatorem. W okresie 2-letniej znajomości przekazał mi szereg ważnych i poufnych informacji z terenu Watykanu, sekretariatu papieskiego oraz Episkopatu Polski dot. szeroko pojętej problematyki w układzie: Państwo - Kościół i Watykan - Polska. Informacje były prawie zawsze precyzyjne i dogłębne, a przede wszystkim prawdziwe. Wiarygodność informacji sprawdzała się za każdym razem. Jeśli to było konieczne, dołączał on do informacji czasopisma, homilie papieskie, taśmy magnetofonowe. Na podkreślenie

66 Arcybiskup Szczepan Wesoły (ur. 16 X 1926 r. w Katowicach - zm. 28 VIII 2018 r. w Rzymie) święcenia prezbiteratu przyjął w 1956 r. Doktor nauk teologicznych, w latach 1969-2003 biskup pomocniczy gnieźnieński, w latach 1980-2003 delegat ds. duszpasterstwa emigracji polskiej, a w latach 1980-2007 rektor kościoła św. Stanisława Biskupa Męczennika w Rzymie. Od 1994 r. arcybiskup ad personam, a od 2003 r. biskup senior archidiecezji gnieźnieńskiej. Stałe rezydował w Rzymie. W latach 1973-1980 rozpracowywany przez Wydział III Departamentu I MSW w ramach sprawy krypt. „Pasterz”. Zob. AIPN, MSW, 01285/208/J, Wesoły Szczepan; AIPN, MSW, 003322/1, Karta o symbolu EOK-6/74 z kartoteki księży katolickich dot. Szczepana Wesołego; AIPN, MSW, 003322/1, Załącznik do karty o symbolu EOK-6/63 z kartoteki księży katolickich dot. Szczepana Wesołego; AIPN, MSW, 2912/1 Karta o symbolu EOK-6-A z kartoteki księży katolickich dot. Szczepana Wesołego.

67 Cyt. AIPN, Zarząd II SG WP, 2602/27084, Sprawozdanie pracownika rezydentury płk. Franciszka Mazurka „Barcza” z pracy za granicą we Włoszech za okres od 4 I 1982 r. do 30 VI 1987, [Warszawa] 17 VIII 1987 r., k. 35 . W okresie stanu wojennego ks. Marian Burniak miał stwierdzić, że nie będzie występować przeciwko gen. Wojciechowi Jaruzelskiemu, wbrew zaleceniom hierarchii kościelnej, „bo nie znajduje żadnych dowodów, iż generał walczy z kościołem, a wręcz przeciwnie nawołuje tylko do zgody i pojednania narodu”. Cyt. ibidem, k. 35. 
zasługuje fakt, że chętnie przyjmował propozycje różnych spotkań, nie wykazywał żadnych podejrzeń, dzielił się informacjami w sposób naturalny. Jest też faktem, że systematycznie stwarzałem z mojej strony sprzyjający klimat do takich kontaktów (stosowanie różnorodnych ulg taryfowych biletowych i bagażowych, bezpłatne bilety lotnicze dla zainteresowanego i wskazanych przez niego osób, ułatwienia rezerwacyjne itp.). Równocześnie stosowałem zasadę zagęszczania i zacieśniania kontaktów, przerzucania ich z płaszczyzny służbowej na prywatną, a więc bardziej swobodną. Rezerwowałem fikcyjnie w Domu Pielgrzyma pokoje hotelowe, zamawiałem dla znajomych wizyty na audiencje papieskie, co pozwalało mi nawet odwiedzać ks. S[tanisława] $\mathrm{H}$ [ejmo] ad hoc bez uprzedzenia $\mathrm{z}$ myślą o uzyskaniu lub potwierdzeniu ważnych informacji”68. Hejmo został oficjalnie przekazany następcy Mazurka podczas przyjęcia w Domu Pielgrzyma, które odbyło się 17 czerwca 1987 r. Jedenaście dni później Franciszek Mazurek i Jan Mich ${ }^{69}$ byli obecni na audiencji u papieża, którą zorganizował Hejmo, a która miała przynieść „przesłankę korzystnej współpracy w zakresie handlo[wo]-przewozowej oraz w zakresie kontaktów informacyjnych interesujących naszą instytucję"70;

- ks. Janem Piekarskim - „Nawiązałem z nim kontakty na początku mojego pobytu we Włoszech, co mi znacznie pomogło przy wchodzeniu w środowisko kościelne. Długoletni pobyt ks. J[ana] P[iekarskiego] w Rzymie, szerokie kontakty w polskich kręgach kościelnych we Włoszech powodują, że dysponuje on szeregiem ciekawych aczkolwiek często oderwanych i nieuporządkowanych informacji $z$ terenu Watykanu

68 Cyt. AIPN, Zarząd II SG WP, 2602/27084, Sprawozdanie pracownika rezydentury płk. Franciszka Mazurka „Barcza” z pracy za granicą we Włoszech za okres od 4 I 1982 r. do 30 VI 1987, [Warszawa] 17 VIII 1987 r., k. 35-37.

69 Jan Marek Mich (ur. 7 X 1945 r. w Załuskach) członkiem PZPR był od 1970 r. W tym też roku ukończył Wydział Finansów i Statystyki w Szkole Głównej Planowania i Statystyki. Od 1971 r. pracował jako akwizytor w PLL „LOT”, z tego względu już w 1972 r. został zwerbowany przez Zarząd II SG WP. W 1974 r. Oddział „R” (germańsko-skandynawski) wywiadu wojskowego planował go ukadrowić, na co Mich przystał. Jednak ze względu na brak możliwości wykorzystania go poza granicami kraju odstąpiono od tego. W 1977 r. przejął „Cezara” Oddział X (terenowy), ale ze względu na planowany wyjazd do Tunezji, gdzie miał objąć funkcję przedstawiciela PLL „LOT” w Tunisie, przejął go ostatecznie Oddział IV (anglo-amerykański). W latach 1977-1983 pracował pod przykryciem w rezydenturze „Palma” w Tunisie. Po 1983 r. Mich podlegał Oddziałowi „C” (stołecznemu), a od 1987 r. Oddziałowi „K” (krajów europejskich) ze względu na planowany wyjazd do Włoch. Pełnił wówczas funkcję zastępcy kierownika Wydziału Handlowego PLL „LOT”. AIPN, Zarząd II SG WP, 2602/22922, Teczka personalna współpracownika ps. „Cezar”; AIPN, Zarząd II SG WP, 2602/16193, Teczka nr 046/77, Wyciąg spraw operacyjnych z teczki współpracownika ps. „Cezar”, 1977-1983.

70 Cyt. AIPN, Zarząd II SG WP, 2602/27084, Sprawozdanie pracownika rezydentury płk. Franciszka Mazurka „Barcza” z pracy za granicą we Włoszech za okres od 4 I 1982 r. do 30 VI 1987, [Warszawa] 17 VIII 1987 r., k. 37. 
i którymi to informacjami dzielił się ze mną podczas różnorakich, najczęściej roboczych spotkan'”71;

- ks. dr. Janem Kupką - „Przekazał mi szereg pozycji wydawniczych pochodzących z ich paryskiej drukarni, między innymi, polityczny kwartalnik katolicji [tak w oryginale, miało być: katolicki] „Znaki Czasu” redagowany $\mathrm{w}$ Wiedniu przez $\mathrm{A}$ [ndrzeja] Micewskiego ${ }^{72}$, któremu to czasopismu patronuje ks. prymas J[ózef] Glemp"73.

W sprawozdaniach do centrali wywiadu wojskowego informatorów ukrywano pod literami: „B” (ks. Lorek), „C” (ks. Karpiński), „D” (ks. Burniak), „E” (ks. Piekarski) bądź symbolami: BA-9 (źródło niezidentyfikowane), B-10

\footnotetext{
71 Cyt. ibidem, k. 37-38.
}

72 Andrzej Micewski (ur. 3 XI 1926 r. w Warszawie - zm. 29 XI 2004 r. w Warszawie) historyk, żołnierz AK, działacz katolicki, publicysta i autor książek historycznych, współpracownik Stowarzyszenia „PAX”, miesięcznika „Więź” i Klubu Inteligencji Katolickiej (dalej: KIK), jeden z doradców prymasa Józefa Glempa w okresie stanu wojennego, poseł na Sejm RP II kadencji z ramienia PSL. Zarejestrowany do nr 1203 przez Wydział II Departamentu IV MSW w charakterze tajnego współpracownika ps. „Michalski” i prowadzony co najmniej od 1967 r. Następnie zarejestrowany jako figurant Sprawy Operacyjnego Rozpracowania krypt. „Aza” o nr 52821. W 1980 r. ponownie pozyskany przez Departament IV MSW w charakterze tajnego współpracownika o nr 62414 i zarejestrowany. Wyeliminowany z sieci agenturalnej 15 II 1982 r. Materiały zostały zmikrofilmowane i złożone do archiwum Biura „C” MSW. Zarejestrowany przez Wydział II Departamentu IV MSW jako figurant kwestionariusza ewidencyjnego ps. „Aza” o nr 75208. W 1986 r. sprawę przejął Wydział III Departamentu I MSW. Materiały operacyjne zakończono 2 II 1989 r. i złożono do archiwum Biura „C” MSW. Występuje również w materiałach Sprawy Obiektowej krypt. „Oaza” założonej przez SB na KIK. AIPN, MSW, 00191/14, Teczka personalna tajnego współpracownika ps. „Michalski”; AIPN, MSW, 0716/218, t. 1-3, Micewa Micewski Andrzej [Kwestionariusz Ewidencyjny krypt. „Aza”]; AIPN, MSW, 0712/32, Sprawa obiektowa kryptonim „Oaza” dot. Klubu Inteligencji Katolickiej; A. Friszke, „Tygodnik Solidarnośc” 1981, „Biuletyn IPN” 2005, nr 7-8, s. 21-50.

73 Cyt. AIPN, Zarząd II SG WP, 2602/27084, Sprawozdanie pracownika rezydentury płk. Franciszka Mazurka „Barcza” z pracy za granicą we Włoszech za okres od 4 I 1982 r. do 30 VI 1987, [Warszawa] 17 VIII 1987 r., k. 38. 
i BA-10 (ks. Głódźn $\left.{ }^{74}\right)$, B-11 i BA-11 (ks. Karpiński), B-12 i BA-12 (ks. Lorek) ${ }^{75}$, B-13 i BA-13 (o. Hejmo), B-14 i BA-14 (ks. Burniak) ${ }^{76}$.

Wszystkie sprawy kościelne podlegały Oddziałowi „Y” (agenturalnemu) Zarządu II SG WP, który w raportach występował pod krypt. „Sowa” i były omawiane bezpośrednio z jej szefem, płk. Henrykiem Dunalem ${ }^{77}$ bądź płk. Zdzisławem Żyłowskim, ps. „Jacek”.

Wszyscy księża z którymi spotykał się „Barcz” traktowani byli jako informatorzy ${ }^{78}$. Podobnie rozpracowywany przez „Rafała” ks. Rakoczy był traktowany jako kandydat na informatora świadomego.

$\mathrm{Z}$ definicji informatorem wywiadu Sił Zbrojnych PRL (świadomym bądź nieświadomym) mógł być obywatel obcego państwa, bezpaństwowiec bądź obywatel polski mieszkający na stałe za granicą lub wyjeżdżający z kraju, który w ramach „ułożonych stosunków” (nie musiał formalnie wyrazić zgody na współpracę $\mathrm{z}$ wywiadem, $\mathrm{z}$ reguły odbywało się to $\mathrm{w}$ ramach dobrych

74 Charakteryzowany podobnie jak ks. Głódź, miał należeć do grupy młodych księży, która wywierała wpływ na decyzje papieskie głównie w sprawach polskich. Zob. AIPN, Zarząd II SG WP, 2602/27084, Sprawozdanie roczne z pracy „Barcza” za rok 1985, [Rzym grudzień 1985 r.], k. 58.

75 W 1982 r. wprost Lorek, jeszcze jako student, nazywany był kontaktem informacyjnym. Zob. AIPN, Zarząd II SG WP, 2602/16173, Załącznik do pisma 1/83 dot. oceny rezydentury rzymskiej za 1982 r., 31 XII 1982 r., k. 149. W 1986 r. centrala Zarządu II SG WP zrezygnowała z BA-12 (był na kontakcie Departamentu I MSW), a BA-11 „utracił możliwości wywiadowcze". Podtrzymywano kontakty z BA-10, BA-13, BA-14, które chciano przekazać następcy „Barcza”, współpracownikowi Janowi Markowi Michowi, ps. „Cezar”. Zob. AIPN, Zarząd II SG WP, 2602/22060, Załącznik nr 1 do pisma nr 1/87, [Warszawa] 9 I 1987 r., k. 8; Tezy do rozmów z ppłk. Witem Łączyńskim przybywającym do kraju w dniu [Warszawa] 6 III 1987 r., k. 40.

76 Zob. AIPN, Zarząd II SG WP, 2602/27084, Załącznik nr 5 do pisma nr 6/86 dot. tematyki pracy w okresie I półrocza [1986 r.], [Rzym 1986 r.], k. 53-54; Sprawozdanie z pracy za okres I półrocza 1985 r., [Rzym 1985 r.], k. 72-75; AIPN, Zarząd II SG WP, 2602/22073, Ocena pracy rezydentury „Góra” za I półrocze 1986 r., [Warszawa czerwiec 1986 r.], k. 187.

77 Pułkownik Henryk Dunal (ur. 3 I 1937 r. w Rokitnie). Członek PZPR od 1956 r., w Siłach Zbrojnych PRL od 1 IX 1955 r., najpierw służył w Korpusie Bezpieczeństwa Publicznego, następnie w Zarządzie II SG WP po linii politycznej. W latach 1971-1974 rzeczoznawca attaché w Paryżu, następnie starszy oficer Oddziału IV (anglo-amerykańskiego) na kierunku francuskim, a w latach 1979-1980 attaché wojskowy w Paryżu, w 1982 r. ukończył dwumiesięczny kurs przy Akademii Dyplomatycznej ZSRS, od 1983 r. szef Oddziału „Y” (agenturalnego), a od 1986 r. attaché wojskowy w Libanie, od 1989 r. p.o. zastępcy szefa Zarządu II SG WP ds. operacyjnych, od 1990 r. attaché wojskowy w Pekinie. W 1992 r. przeszedł do rezerwy w stopniu pułkownika. Używał pseudonimu „Uran” i nazwisk legalizacyjnych Darski, Danek, Kowalski. Znany osobiście i z akt kpt. Jerzemu Sumińskiemu. Zob. AIPN, MON, 2174/7388, Akta personalne Henryka Dunala; AIPN, Zarząd II SG WP, 2602/28201, Kserokopia kart pracowników Zarządu II, k. 45-46; katalog IPN, https://katalog.bip.ipn.gov. pl/informacje/65001 (dostęp: 19 III 2018 r.).

78 AIPN, Zarząd II SG WP, 2602/16173, Pismo nr 7/83, [Rzym] 8 VII 1983 r., k. 213. 
stosunków osobistych) z pracownikiem wywiadu przekazuje dokumenty lub informacje interesujące wywiad. „Świadomość informatora” to nic innego jak ujawnienie mu, z kim ma do czynienia. Oficer wywiadu ujawniał się przed osobowym źródłem i mógł go w ten sposób lepiej wykorzystać, ponieważ mógł je ukierunkowywać i zadaniować, co było istotną sprawą dla wywiadu. W punkcie 53 instrukcji o pracy operacyjnej Zarządu II SG WP wprowadzonej w życie zarządzeniem szefa wywiadu wojskowego 15 grudnia 1976 r. możemy przeczytać: „Cechami odróżniającymi informatora od agenta są:

- wykorzystanie kontaktu jest uwarunkowane ułożeniem dobrych stosunków osobistych z określonym pracownikiem wywiadu, a nie instytucjonalnych, np. z wywiadem;

- ograniczone tematycznie lub czasowo możliwości informacyjne;

- kontakty informatora $\mathrm{z}$ pracownikiem wywiadu winny być odpowiednio legendowane, lecz nie zawsze będę warunki do utrzymania ich w ścisłej tajemnicy;

- występowanie innych czynników, wykluczających możliwość ułożenia współpracy na płaszczyźnie agenturalnej"79.

Nieświadomy informator był jednak, szczególnie w kręgach kościelnych, bezpiecznym źródłem, bo nie zachodziła obawa dekonspiracji. Trudniej jednak zdobywano wiadomości, bo takiego informatora nie można było wprost spytać o rzeczy interesujące wywiad, by nie domyślił się rzeczywistej roli oficera pod przykryciem. Punkt 69 instrukcji o zasadach naboru, legalizacji i pracy oficerów pod przykryciem urzędów i instytucji cywilnych PRL z 25 listopada 1975 r. nakazywał: „Oficerom pod przykryciem nie wolno:

- w żadnym wypadku naruszać podstawowych zasad konspiracji, obowiązujących każdego pracownika polskiego wywiadu wojskowego;

- naruszać ustalonej i obowiązującej pod przykryciem legendy.

Oficer pod przykryciem powinien być wzorem zdyscyplinowania, skromności, rzetelności i uczciwości; cechować go winna zdrowa ambicja, czujność i nieustanne dążenie do osiągania jak najlepszych wyników w swej zaszczytnej służbie.

Postępowanie oficera w służbie i poza służbą winno być zgodne z podstawowymi zasadami etyki, obowiązującymi kadrę ludowego Wojska Polskiego" ${ }^{80}$.

\footnotetext{
79 Cyt. AIPN, Biblioteka byłych wojskowych organów bezpieczeństwa państwa polskiego, 2603/242, Instrukcja o pracy operacyjnej Zarządu II Sztabu Generalnego WP, Warszawa 1976, s. 32-33.

80 Cyt. AIPN, Biblioteka byłych wojskowych organów bezpieczeństwa państwa polskiego, 2603/395, Instrukcja o zasadach naboru, legalizacji i pracy oficerów pod przykryciem urzędów i instytucji cywilnych PRL, Warszawa 1975, s. 27-28.
} 
Materiały od informatora nieświadomego miały z reguły charakter informacyjny, a nie operacyjny. Pod względem ważności materiał taki mógł być jednak oceniany przez centralę wywiadu wojskowego na równi z materiałem operacyjnym. Pytanie, czy takie nieświadome „źródło” mogło komukolwiek zaszkodzić? Oczywiście że tak, bo główne informacje, jakie przekazywał, nawet charakteru plotkarskiego, mogły być wykorzystane nawet nie tyle przez Zarząd II SG WP, ale przede wszystkim przez Departament I (wywiad cywilny) i IV (tzw. pion antykościelny) MSW w rozpracowaniu kolejnych kandydatów na osobowe źródła informacji czy figurantów spraw ewidencyjnych. Co więcej, informacje takie mogły być dalej wykorzystywane przez aparat partyjny przy kontaktach i rozmowach z władzami kościelnymi. Jak wyraźnie podkreślał podręcznik szkoleniowy wywiadu wojskowego: „Praca informacyjna jest ważną częścią składową działalności wywiadowczej, której zadaniem jest ewidencjonowanie, systematyzowanie, studiowanie, analizowanie, uogólnianie i ocena zdobytych materiałów i informacji oraz sporządzanie na ich podstawie odpowiednich dokumentów informacyjnych (opracowania, notatki, parafrazy) dla informowania kierownictw partyjno-rządowego, kierownictwa Ministerstwa Obrony Narodowej i Sił Zbrojnych PRL”81. Potwierdza to zapis w jednej z opinii: „W/w [chodzi o źródła BA-10, BA-11, BA-12, BA-13 - przyp. BK] uzyskiwali i przekazywali cenne informacje, które wykorzystane były do informowania kierownictwa państwowego" ${ }^{\text {. }}$.

Nie wiemy, jakie wiadomości informatorzy przekazywali „Barczowi” podczas rozmów, ale w 1987 r. centrala wywiadu wojskowego bardzo wysoko oceniała ich informacje dot. spraw polsko-watykańskich i watykańskich ${ }^{83}$. Według jednego z podręczników szkoleniowych wywiadu wojskowego sposób prowadzenia rozmów był kluczowy: „Prowadzenie rozmów jest jednym z podstawowych sposobów zdobywania informacji. Sposób ten z reguły stosują wszyscy pracownicy kadrowi, współpracownicy, agenci i informatorzy świadomi. Wyniki rozmów zależą od wielu czynników, a przede wszystkim od: warunków i sytuacji, stopnia przygotowania wywiadowczego, elokwencji i wiedzy, znajomości danego języka oraz doboru rozmów i umiejętności doboru tematu rozmów przez członków ogniw wywiadu wojskowego" ${ }^{34}$.

\footnotetext{
81 Cyt. AIPN, Biblioteka byłych wojskowych organów bezpieczeństwa państwa polskiego, 2603/13350, Praca informacyjna rezydentur, OS ZII SG WP, Warszawa 1977, s. 4.

82 Cyt. AIPN, SWSW, 2386/32332, Ocena pracy kadrowego pracownika ppłk. Wita Łączyńskiego za okres pobytu na placówce w Rzymie od 10 IX 1983 r. do 16 IV 1987 r., [Warszawa] 12 V 1987 r., k. 96.

83 AIPN, Zarząd II SG WP, 2602/22060, Załącznik nr 1 do pisma nr 2/87, 13 II 1987 r., k. 29.

84 Cyt. AIPN, Biblioteka byłych wojskowych organów bezpieczeństwa państwa polskiego, 2603/13350, Praca informacyjna rezydentur, OS ZII SG WP, Warszawa 1977, s. 38.
} 
Centrala wywiadu wojskowego doceniała Mazurka także w latach wcześniejszych, kiedy oficer ten uzyskał informacje oparte „na wiarygodnych danych pochodzących z sekretariatu papieskiego, sekretariatu stanu i Domu Polskiego" ${ }^{35}$. Uznanie to spotkało się z nagrodzeniem „Barcza” dodatkiem w wysokości 150 dolarów miesięcznie na poszczególne kwartały w latach 1985-1986 r. ${ }^{86}$ Dodatkowo „Barcz” przesyłał wiele wydawnictw o tematyce kościelnej i dot. samego Watykanu, m.in. katalog telefoniczny Watykanu ${ }^{87}$. Już w 1984 r. możemy przeczytać, że: „Szczególne nacelowanie poszło na BA-10 posiadające dobre rozpoznanie środowiska i sytuacji w Watykanie. Dotychczasowe kontakty układają się pomyślnie. BA-10 nie unika spotkań, podejmuje otwarcie wymianę poglądów na wszelkie zagadnienia natury politycznej i personalnej”88. I rzeczywiście, w tym czasie sporo materiałów wysyła „Barcz” dla „Sowy”, jednak nieliczne są opisane, że dot. B-10 ${ }^{89}$.

Już w 1985 r. źródło B-10 miało być przejęte przez Oddział „K” (krajów europejskich), ukierunkowane i wykorzystywane jako informator ${ }^{90}$. Być

85 Cyt. AIPN, Zarząd II SG WP, 2602/27084, Tematyka pracy w okresie I półrocza [1986 r.], [Rzym 1986 r.], k. 53.

86 AIPN, Zarząd II SG WP, 2602/27084, Wniosek o przyznanie kwartalnego dewizowego dodatku operacyjnego z okres I kwartał 1986 r., [Rzym 1986 r.], k. 52; Wniosek o przyznanie kwartalnego dewizowego dodatku operacyjnego za okres III kwartał 1985 r., 10 VII 1985 r., k. 67; AIPN, Zarząd II SG WP, 2602/16610, Parafraza depeszy do ppłk. Łączyńskiego do Rzymu, [Warszawa] 7 X 1985 r., k. 333; AIPN, Zarząd II SG WP, 2602/22060, Załącznik nr 1 do pisma nr 1/87, [Warszawa] 9 I 1987 r., k. 4. W 1983 r. „Barcz” został nagrodzony dodatkiem 75 dolarów w skali miesięcznej oraz specjalną nagrodą szefa Zarządu II SG WP w wysokości 300 dolarów z okazji 40 rocznicy ludowego Wojska Polskiego. Dodatek był wypłacony za rozpracowanie księży i podjęcie rozmów z nimi. Zob. AIPN, Zarząd II SG WP, 2602/22905, Załącznik do pisma nr 6/83, [Warszawa] 18 VI 1983 r., k. 159; Wniosek o przyznanie kwartalnego dewizowego dodatku operacyjnego za okres II kwartału 1985 r., [Warszawa] 1 VII 1983 r., k. 160; AIPN, Zarząd II SG WP, 2602/16173, Pismo nr 7/83, [Warszawa] 8 VII 1983 r., k. 213; Parafraza depeszy do Rzymu, [Warszawa] 10 X 1983 r., k. 262. W 1985 r. za całokształt pracy Mazurek został nagrodzony medalem czterdziestolecia Polski Ludowej. Zob. Pismo nr 6/85, [Rzym] 7 VI 1985 r., k. 255.

87 AIPN, Zarząd II SG WP, 2602/27084, Załącznik nr 4 do pisma nr 12/84, dot. sprawozdania z realizacji zadań w 1984 r., [Rzym 1985 r.], k. 83. Zob. także: AIPN, Zarząd II SG WP, 2602/22060, Załącznik nr 1 do pisma 3/87. Wykaz materiałów informacyjnych, [Rzym] 20 III 1987 r., k. 88.

88 Cyt. AIPN, Zarząd II SG WP, 2602/27084, Załącznik nr 4 do pisma nr 12/84, dot. sprawozdania z realizacji zadań w 1984 r., [Rzym 1985 r.], k. 83. Zob. także: AIPN, Zarząd II SG WP, 2602/16610, Załącznik nr 1 do pisma 2/85, [Warszawa] 14 II 1985 r., k. 197-198.

89 AIPN, Zarząd II SG WP, 2602/16610, Pismo nr 6/84, [Rzym] 23 VI 1984 r., k. 97

90 AIPN, SWSW, 2386/32332, Sprawozdanie ppłk. Wita Łączyńskiego, ps. „Remo” z pracy za granicą we Włoszech za okres od 20 IX 1983 r. do 16 kwietnia 1987 r., [Rzym przełom kwietnia/maja 1987 r.], k. 78. Pozytywnie oceniany był także B-13 (o. Hejmo). Ibidem, k. 80. „Na pierwszym planie jest B-10” - cyt. AIPN, Zarząd II SG WP, 2602/27084, Sprawozdanie z pracy za okres I półrocza 1985 r., [Rzym 1985 r.], k. 73. 
może właśnie ukierunkowanie źródła spowodowało, że ks. Głódź zorientował się, z kim ma do czynienia i zaczął się wycofywaćị .

W jednej z opinii możemy przeczytać: „Ocenia się, że BA-10, BA-11, BA13 będąc informatorami przekazywali informację typu agenturalnego", co by świadczyło nie tylko o ważności tych informacji, ale o roli informatorów ${ }^{92}$. Ze sprawozdania rezydenta z 1983 r. wynika jednak, że ks. Karpiński i ks. Głódź byli świadomymi informatorami ${ }^{93}$. W 1987 r., wymieniając kontakty „Barcza”: BA-10, BA-13, BA-14, podano, że są wykorzystywani jako informatorzy świadomi i nieświadomi, nie wskazując dokładnie, którzy z nich mogą być informatorem świadomym, ale dodano, że: „Najwięcej informacji (przydatnych i wartościowych) przekazuje BA-13"94. Najbardziej aktywnymi informatorami płk. Mazurka był ks. Głódź i o. Hejmo. Pytanie, kogo uważano za świadome źródło, pisząc: „B-10, B-13, B-14 - kontakty «Barcza» w środowisku watykańskim. Wszyscy wykorzystywani jako świadomi i nieświadomi informatorzy. Jako główni informatorzy: B-10 i B-13. Kontakty te dają nam wiele ważnych informacji, w tym dla szczebla państwowego"95.

Zarząd II SG WP bardzo delikatnie podchodził do kontaktów z księżmi. Widać to wyraźnie na podstawie zachowanych akt i poszczególnych planów działania. Między innymi dotyczy to spotkań, na które w końcu zdecydowali się oficerowie centrali Zarządu II SG WP, a które to zabezpieczała

91 T. Krzyżak, A. Gajcy, Armia PRL kontra Papież..., s. 8-9.

92 AIPN, SWSW, 2386/32332, Ocena pracy kadrowego pracownika ppłk. Wita Łączyńskiego za okres pobytu na placówce w Rzymie od 10 IX 1983 r. do 16 IV 1987 r., Warszawa 12 V 1987 r., k. 96.

93 „W latach 1980-[19]83 rezydentura pozyskała 6 świadomych informatorów: «Silver», «Rid», «Gioni», «Mark», Głódź i Karpiński”. A dalej: „Z informacji uzyskanych od Głodzia i Karpińskiego (sprawy prowadzone przez płk. Mazurka) przekazano do Centrali ok. 10 depesz informacyjnych ocenionych jako wartościowe". Cyt. AIPN, Zarząd II SG WP, 2602/28311, Sprawozdanie rezydenta - kmdr. por. Czesława Wawrzyniaka, ps. „Rafał” z pracy za granicą w Rzymie za okres 15 IX 1979 r. - 1 X 1983 r., [Rzym] 29 X 1983 r., k. 264.

94 Cyt. AIPN, Zarząd II SG WP, 2602/22060, Sprawozdanie z pracy rezydentury „Góra” w I półroczu 1987 r., [Rzym] 18 VI 1987 r., k. 174.

95 Cyt. AIPN, Zarząd II SG WP, 2602/22073, Sprawozdanie z pracy rezydentury w roku sprawozdawczym 1986, [Rzym] 18 XII 1986 r., k. 334. 
rezydentura (ppłk Wit Łączyński i płk Franciszek Mazurek ${ }^{96}$ ). Takie spotkania odbywały się zarówno z ks. Lorkiem ${ }^{97}$, jak i ks. Głodziem ${ }^{98}$.

Jeszcze przed wyjazdem do kraju zarówno rezydentura, jak i centrala wywiadu jednogłośnie uznały, że Mazurek „obsługuje operacyjnie, systematycznie 3 ważne źródła osobowe w Watykanie (B-10, B-12, B-13) i uzyskuje ważne pod względem państwowym informacje" ${ }^{\text {"99. }}$.

Współpracownikiem Zarządu II SG WP i jednocześnie następcą Mazurka był Jan Marek Mich, ps. „Cezar”100, który przejął trzech informatorów: B-10, B-13 oraz B-14, z czego o. Hejmo miał być "najbardziej efektywny”. Mich od 1987 r. pełnił funkcję kierownika Przedstawicielstwa PLL „LOT” w Rzymie. Z zadań postawionych przez Zarząd II SG WP „Cezarowi” do realizacji we Włoszech należało typowanie i rozpracowywanie kandydatów do tzw. aparatu tajnego, wyszukiwanie nowych źródeł informacji, w tym ze środowiska watykańskiego, „przejęcie i wykorzystanie watykańskich osobowych źródeł informacji (BA-10, BA-13)", przedstawianie opracowań i notatek dot. sytuacji wywiadowczej we Włoszech oraz zdobywanie dokumentów legalizacyjnych i materiałów interesujących centralę wywiadu wojskowego $^{101}$. Do szkolenia Micha w tematyce watykańskiej zostali włączeni oficerowie wywiadu: ppłk Wit Łączyński i płk Franciszek Mazurek. „Podczas szkolenia szczególną uwagę zwrócono na problematykę watykańską, możliwości i sposoby prowadzenia w tym środowisku działalności wywiadowczej z uwzględnieniem wykorzystania informatorów BA-10 i BA-13"102. W zada-

96 AIPN, SWSW, 2386/32332, Sprawozdanie ppłk. Wita Łączyńskiego, ps. „Remo” z pracy za granicą we Włoszech za okres od 20 IX 1983 r. do 16 kwietnia 1987 r., [Warszawa przełom kwietnia/maja 1987 r.], k. 87.

97 AIPN, Zarząd II SG WP, 2602/27084, Wniosek o przyznanie kwartalnego dewizowego dodatku operacyjnego za okres III kwartał 1985 r., [Warszawa] 10 VII 1985 r., k. 67.

98 AIPN, Zarząd II SG WP, 2602/27084, Załącznik nr 23 do pisma nr 8/85, [Rzym 1985 r.], k. 68. „Barcz w roku 1984 realizował zgodnie z wytycznymi Centrali rozpracowanie B-10 oraz wykorzystywał go informacyjnie, doprowadził do nawiązania kontaktu przedstawiciela Centrali z B-10”. Cyt. AIPN, Zarząd II SG WP, 2602/27084, Załącznik nr 5 do pisma 3/85 dot. przyznania „Barczowi” dodatku za I kwartał 1985 r., [Rzym] 22 III 1985 r., k. 77.

99 Cyt. AIPN, Zarząd II SG WP, 2602/22073, Załącznik nr 4 do pisma nr 4/86 dot. wniosku o przyznanie kwartalnego dodatku operacyjnego za I kwartał 1986 r. dla „Barcza”, Rzym 19 IV 1986 r., k. 105; Sprawozdanie z pracy rezydentury w I-ej połowie 1986 r., [Rzym] 21 VI 1986 r., k. 144-145.

100 Zob. przyp. 69.

101 AIPN, Zarząd II SG WP, 2602/22922, Instrukcja do pracy wywiadowczej za granicą we Włoszech dla Jana Micha ps. „Cezar”, [Warszawa] 26 V 1987 r., k. 122-123. Stamtąd też cytat. Zob. AIPN, Zarząd II SG WP, 2602/22922, Załącznik nr 6 do pisma 6/87 dot. zadań dla współpracownika „Cezar” - „C” Jan Mich, [Rzym] 15 VI 1987 r., k. 125.

102 Cyt. AIPN, Zarząd II SG WP, 2602/22922, Sprawozdanie z przeprowadzonego szkolenia wywiadowczego współpracownika ps. „Cezar”, [Warszawa] 3 VI 1987 r., k. 124. 
niach do realizacji na 1988 r. centrala wywiadu wskazała rozpracowywanie i wykorzystywanie dodatkowo BA-14 (ks. Burniaka) ${ }^{103}$.

W 1988 r. rezydentura „Góra” została słabo oceniona, uważano, że informowano centralę wywiadu wojskowego „o sprawach mało ważnych, niezwiązanych z siłami zbrojnymi [włoskimi i NATO - przyp. BK], a dot. problematyki watykańskiej"104. Aktywność samego Jana Micha w latach 1987-1988 była oceniana zarówno przez rezydenturę w Rzymie, jak i centralę wywiadu na ocenę dostateczną ${ }^{105}$. Zarzucano współpracownikowi, że „Obecnie nawiązane kontakty w środowisku kleru watykańskiego pozwalają mu na bardziej efektywne uzyskiwanie interesujących informacji. Także z pozycji oficjalnie wykonywanych obowiązków posiada możliwości do nawiązania interesujących znajomości pod kątem typowania osób do aparatu wywiadowczego. Możliwości te wykorzystuje jednak w minimalnym stopniu"106. W 1989 r. oprócz zadań typowniczo-werbunkowych i zbierania informacji o sytuacji wywiadowczej centrala wywiadu wojskowego kazała kontynuować rozpracowanie i wykorzystywanie informatorów BA-10, BA-13 i BA-14 ${ }^{107}$. Zresztą w pierwszym półroczu $1989 \mathrm{r}$. uznała pracę Micha za efektywną, bo rezydentura dostarczyła osiem depesz od informatorów B-10 i B-13 dot. oceny środowiska watykańskiego na temat sytuacji $\mathrm{w}$ Polsce ${ }^{108}$. Najefektywniejszym w tym czasie informatorem miał być o. Hejmo, z którym zaczął się spotykać dodatkowo współpracownik ps.

103 AIPN, Zarząd II SG WP, 2602/22922, Załącznik nr 9 do pisma 2/88 dot. zadań do realizacji w 1988 r. przez „Cezara”, [Warszawa] 3 II 1988 r., k. 127.

104 AIPN, Zarząd II SG WP, 2602/27152, Załącznik nr 1 do pisma 2/89, [Warszawa] 20 II 1989 r., k. 27. Zob. także T. Krzyżak, Armia zagląda Papieżowi do talerza..., s. 15. Trzeba jednak zaznaczyć, że w latach 1987-1988 nastąpiła zmiana w polityce władz komunistycznych względem Kościoła katolickiego, stąd może wynikać niepochlebna ocena działalności rezydentury „Góra”. Zob. J. Żaryn, Dzieje Kościoła katolickiego..., s. 564-567; K. Michalski, Działalność Komisji Wspólnej przedstawicieli Rządu PRL i Episkopatu Polski 1980-1989, Warszawa 2012, s. 182-199.

105 AIPN, Zarząd II SG WP, 2602/22060, Sprawozdanie z pracy rezydentury „Góra” w roku 1987, [Rzym] 16 XII 1987 r., k. 359 i 371; AIPN, Zarząd II SG WP, 2602/22922, Ocena pracy „Cezara” za 1988 rok, [Rzym początek 1989 r.], k. 135.

106 Cyt. AIPN, Zarząd II SG WP, 2602/22922, Ocena pracy „Cezara” za 1988 rok, [Rzym początek 1989 r.], k. 135.

107 AIPN, Zarząd II SG WP, 2602/22922, Załącznik nr 7 do pisma 2/89 dot. zadań do realizacji w 1989 r. przez „Cezara”, [Warszawa] 11 II 1989 r., k. 136.

108 Nie uchroniło to „Cezara” od wystawienia przez centrale wywiadu oceny dostatecznej za całokształt jego pracy wywiadowczej. Zob. AIPN, Zarząd II SG WP, 2602/22922, Ocena pracy „Cezara” za I półrocze 1989 r., [Rzym wrzesień 1989 r.], k. 141. W tym przypadku oba osobowe źródła nazwane zostały informatorami nieświadomymi, zob. AIPN, Zarząd II SG WP, 2602/22922, Tezy do rozmowy ze współpracownikiem „Cezar” przebywającym w kraju na urlopie wypoczynkowym w dn. 9 IX 1989 r., [Warszawa] 8 IX 1989 r., k. 138. 
„Gustaw”109. W 1990 r. „Cezar” dalej miał spotykać się z ks. Głodziem i o. Hejmo, gdyż te rozmowy centrala Zarządu II SG WP oceniała dobrze. Jednak przy podsumowaniu pierwszego półrocza $1990 \mathrm{r}$. okazało się, że nawet te spotkania przysparzają „Cezarowi” trudności ${ }^{110}$. Sam rezydent ps. „Maxime” tłumaczył jednak Micha, że „w związku z zaistniałymi zmianami w życiu społeczno-politycznym naszego kraju obsługiwane przez «Cezara» źródła stały się mało interesujące. Dlatego też spadła ilość informacji przydatnej do wykorzystania"111.

Ponieważ nie znamy szczegółów przekazywanych informacji przez księży ze środowiska watykańskiego, szczególnie ks. Głodzia, ks. Lorka, ks. Karpińskiego, ks. Burniaka czy o. Hejmo, nie możemy wprost ocenić szkodliwości tych informacji. Na przykład 12 czerwca $1986 \mathrm{r}$. płk Mazurek przekazał do centrali wywiadu wojskowego "skoroszyt wraz z dokumentacją dot. kontaktów watykańskich", niestety, skoroszyt ten nie zachował się, podobnie jak szczegółowe meldunki „Barcza” ze spotkań. W zachowanych materiałach widać jednak wyraźnie, że informacje dla wywiadu wojskowego były interesujące i wartościowe ${ }^{112}$. Jedynie w przypadku ks. Lorka zachowała się lista publikacji, które przekazał w 1985 r. ppłk. Mazurkowi. Znalazły się na niej m.in. Claire Sterling - Anatomia zamachu, Bohdana Cywińskiego - Doświadczenie polskie oraz „... potegga jest $i$ basta. Z minionych doświadczeń ruchów społecznych na wsi, Marka Łatyńskiego - Nie paść na kolana. Szkice o opozycji lat czterdziestych, Jacka Kuronia - Polityka i odpowiedzialność, Jana Józefa Lipskiego - KOR.

109 AIPN, Zarząd II SG WP, 2602/27152, Sprawozdanie z pracy rezydentury „Góra” za I półrocze 1989 r., [Rzym] 24 VI 1989 r., k. 110. Pod krypt. „Gustaw” krył się współpracownik wywiadu wojskowego Tadeusz Konon (ur. 28 X 1925 r. w Białymstoku), naczelnik jednego z wydziałów w Ministerstwie Handlu Zagranicznego (dalej: MHZ), od 1972 r. współpracownik wywiadu wojskowego, wykonywał także zadania dla Departamentu I MSW i Szefostwa WSW. W latach 1972-1976 attaché ds. prawno-ekonomicznych w Biurze Radcy Handlowego (dalej: BRH) przy ambasadzie w Kolonii, w latach 1983-1987 radca w BRH przy ambasadzie w Kolonii, od 1987 r. główny specjalista w Departamencie Kadr i Szkolenia MHZ. Brak informacji co do jego działalności po 1987 r. Zob. AIPN, Zarząd II SG WP, 2602/23133, Teczka personalna współpracownika „Gustaw”, 1972-1991 [w rzeczywistości do 1989 r.]. Wiemy jednak, że „Gustaw” trafił do Rzymu, gdzie prowadził działalność typowniczo-werbunkową, ale nie był związany oficjalnie $\mathrm{z}$ ambasadą ani $z$ attachatem. Zob. AIPN, Zarząd II SG WP, 2602/22613, Załącznik nr 2 do pisma 7/89, [Warszawa] 12 VII 1989 r., k. 236; Załącznik nr 5 do pisma 12/89, [Rzym] 5 XII 1989 r., k. 237239; AIPN, 003171/5, t. 2, Wykaz nazwisk i adresów - Rzym, b.m. 12 I 1989 r., k. 562-563.

110 AIPN, Zarząd II SG WP, 2602/22922, Notatka służbowa dot. spotkania ze współpracownikiem ps. „Cezar”, [Warszawa] 16 II 1990 r., k. 146; AIPN, Zarząd II SG WP, 2602/22922, Ocena pracy „Cezara” za I półrocze 1990 r., [czerwiec 1990 r.], k. 147.

111 Cyt. AIPN, Zarząd II SG WP, 2602/22922, Ocena pracy „Cezara” za 1990 r., [Rzym grudzień 1990 r.], k. 148. Nie przeszkodziło to jednak ppłk. Romanowi Oziębale wystawić Michowi ocenę za 1990 r. na dostateczną minus. Zob. ibidem.

112 AIPN, Zarząd II SG WP, 2602/22073, Ocena pracy rezydentury „Góra” za I półrocze 1986 r., [Warszawa czerwiec 1986 r.], k. 187. 
Komitet Obrony Robotników - Komitet samoobrony społecznej i Adama Michnika $-Z$ dziejów honoru w Polsce. Wypisy więzienne ${ }^{113}$.

Dlaczego tak mocno Zarząd II SG WP wszedł wtedy w to środowisko, chcąc mieć wiadomości z bliskiego kręgu papieża i z grupy „nacisku” na niego, czyli tzw. polskiego lobby? Wywiad wojskowy w latach osiemdziesiątych wykorzystał dogodną sytuację, jaka otworzyła się dzięki inicjatywie oficera pod przykryciem, płk. Franciszka Mazurka. Do 1982 r. jakiekolwiek próby zdobycia informatora w kręgu watykańskim, czy to przez Podczaszego, czy Wawrzyniaka, kończyły się niepowodzeniem. Zresztą nie był to kluczowy cel dla Zarządu II SG WP. Samo zainteresowanie papieżem nasiliło się na pewno wcześniej, tj. po zamachu na niego dokonanego przez Alego Agcę 13 maja 1981 r. Wywiad wojskowy został wykorzystany do zacierania śladów wskazujących, że bezpośrednim zleceniodawcą zamachu była Moskwa ${ }^{114}$. Wprowadzenie stanu wojennego w Polsce spowodowało, że Kościół katolicki z terenu Rzymu zaczął wysyłać do Polski paczki z żywnością, ubraniami i lekarstwami. Ta pomoc dla kraju została wykorzystana przez „Barcza” - doświadczonego oficera wywiadu wojskowego - do nawiązania kontaktu $\mathrm{z}$ duchownymi polskimi ${ }^{115}$. Kontakty te zresztą były kontynuowane co najmniej do końca 1990 r. ${ }^{116}$ Od tej pory Zarząd II SG WP mógł pokazać przed Departamentem I i IV MSW, że sam ma możliwość dotarcia do kręgów watykańskich i posiada wartościowe osobowe źródła informacji oraz że jest w stanie przekazywać aparatowi partyjno-politycznemu ciekawe

113 AIPN, Zarząd II SG WP, 2602/16610, Wykaz materiałów informacyjnych, [Rzym] 14 XII 1985 r., k. 394-395.

114 M. Skwara, A. Grajewski, Agca nie był sam, Wokół udziału komunistycznych służb specjalnych w zamachu na Jana Pawła II, Katowice 2015, s. 215-232, zob. także poszczególne protokoły przesłuchań ze śledztwa Oddziałowej Komisji Ścigania Zbrodni przeciwko Narodowi Polskiemu IPN w Katowicach o sygn. S/12/06/Zk.

115 W jednej z ostatnich opinii, jakie wystawił mu rezydent z czerwca 1987 r., możemy przeczytać: „Zadania specjalne wykonuje na wysokim poziomie tak pod względem operacyjnym, jak i informacyjnym, mimo że jest niezwykle mocno o[b]ciążony w pracy oficjalnej. W bieżącym półroczu dostarczał sukcesywnie informacje z tematyki watykańskiej, jak również wojskowej i politycznej. Posiada bogate doświadczenie w zakresie wykonywanej działalności nieoficjalnej, które w umiejętny i efektywny sposób wykorzystuje. Każde zadanie traktuje poważnie i odpowiedzialnie oraz zapewnia wysoki poziom merytoryczny jego realizacji. Ocena pracy za I półrocze [1987 r.] - bardzo dobra”. Cyt. AIPN, Zarząd II SG WP, 2602/22060, Sprawozdanie z pracy rezydentury „Góra” w I półroczu 1987 r., [Rzym] 18 VI 1987 r., k. 179. Gdzie indziej podobnie: „Wykazał duże umiejętności w nawiązaniu interesujących kontaktów w środowiskach kościelnych. Z powodzeniem rozpracowywał i obsługiwał źródła watykańskie”. Cyt. AIPN, Zarząd II SG WP, 2602/22905, Notatka dot. wyróżnienia płk. Franciszka Mazurka nagrodą rzeczową, Warszawa 21 X 1987 r., k. 184. Zob. także pismo płk. Mariana Moraczewskiego do płk. Bogusława Wilczaka, [Warszawa październik-listopad 1985 r.], gdzie materiały z „otoczenia papieża” oceniane są jako wartościowe, AIPN, Zarząd II SG WP, 2602/16610, k. 353.

116 AIPN, Zarząd II SG WP, 2602/22922, Ocena pracy „Cezara” za 1990 r., [grudzień 1990 r.], k. 148. 
wiadomości i materiały. W tym też czasie wywiad wojskowy przejął kompetencje wywiadu cywilnego PRL, wykorzystując nawet ich agenturę. Ten przykład, a można ich wykazać więcej, zaprzecza jednak roli, jaką miał pełnić Zarząd II SG WP jako wywiad wojskowy i udowadnia słuszność zaliczenia go w poczet wojskowego aparatu represji. Co więcej, wywiad wojskowy przy zachodzących zmianach w Polsce przez cały rok 1989 i w 1990 dalej zbierał materiały dot. papieża i tzw. środowiska watykańskiego. Zarząd II SG WP mógł sobie na to pozwolić, bo pozostał poza kontrolą rządu obozu solidarnościowego, a zmiany, jakie zachodziły w wywiadzie, były typowo kosmetyczne, co pozwoliło oficerom uciec od odpowiedzialności i rozliczeń za swoją działalność przed $1990 \mathrm{r}^{117}$ Jeśli przyjrzymy się postaciom oficerów wywiadu wojskowego, zobaczymy, jak w demokratycznej już Polsce dalej służyli, ucząc młodych adeptów wywiadu oraz pełniąc najwyższe funkcje w Wojskowych Służbach Informacyjnych ${ }^{118}$.

\section{Bibliografia}

\section{Archiwalia}

Archiwum Instytutu Pamięci Narodowej

Biblioteka byłych wojskowych organów bezpieczeństwa państwa polskiego

Katalog IPN (online)

Wojewódzki Urząd Spraw Wewnętrznych w Krakowie

Wojewódzki Urząd Spraw Wewnętrznych w Lublinie

Wojewódzki Urząd Spraw Wewnętrznych w Poznaniu

Ministerstwo Spraw Wewnętrznych

Zarząd II Sztabu Generalnego Wojska Polskiego

\section{Publikacje}

Bagieński W., Dwa słowniki wywiadu wojskowego PRL z 1970 i 1978 r. [w:] Studia na wywiadem i kontrwywiadem Polski w XX wieku, t. 1, red. W. Skóra i P. Skubisz, Szczecin 2012.

Bagieński W., Wywiad PRL w Rzymie, „Biuletyn IPN” 2017, nr 1-2, s. 110-127.

Bułhak W., Watykan i szpiedzy z awansu społecznego. Próba portretu zbiorowego kierownictwa wydziału „natowsko-amerykańskiego” i rzymskiej rezydentury „Baszta” Departamentu I (wywiadu) MSW PRL w okresie poprzedzającym pontyfikat Jana Pawta II [w:] Stużby wywiadowcze jako narzędzie realizacji polityki państwa w XX wieku. Wybrane zagadnienia, red. L. Pawlikowicz, R. Zapart, Rzeszów 2014, s. 172-209.

\footnotetext{
117 P. Piotrowski, Nowe służby na nowe czasy. Integracja wojskowych służb specjalnych w latach 1990-1991 [w:] Służby wywiadowcze jako narzędzie..., s. 155-171; T. Kozłowski, Koniec imperium MSW. Transformacja organów bezpieczeństwa państwa 1989-1990, Warszawa 2019, s. 276-284.

118 Na marginesie możemy dodać, że śledząc kariery oficerów wywiadu wojskowego, widzimy, jak kontrwywiad Sił Zbrojnych PRL nie uchronił ich przed dekonspiracją. Większość z nich znana była kpt. Jerzemu Sumińskiemu, oficerowi WSW, ochraniającemu Zarząd II SG WP oraz ppłk. Marianowi Kozłowskiemu - oficerowi wywiadu wojskowego.
} 
Cenckiewicz S., Długie ramię Moskwy. Wywiad wojskowy Polski Ludowej 1943-1991 (wprowadzenie do syntezy), Poznań 2011.

Cenckiewicz S., Atomowy szpieg. Ryszard Kukliński i wojna wywiadów, Poznań 2014.

Grajewski A., Machcewicz P., Żaryn J., Raport: Sprawa o. Konrada Hejmo. Działania Służby Bezpieczeństwa przeciwko Kościołowi katolickiemu w latach 1975-1988, b.d.w. [Warszawa 2005].

Grajewski A., Skwara M., Agca nie był sam, Wokół udziału komunistycznych służb specjalnych w zamachu na Jana Pawła II, Katowice 2015.

Kapuściak B., Wywiad wojskowy PRL. JW 3362 i podległe jej jednostki, „Aparat Represji w Polsce Ludowej 1944-1989” 2016, nr 1 (14), s. 107-154.

Kozłowski T., Koniec imperium MSW. Transformacja organów bezpieczeństwa państwa 1989-1990, Warszawa 2019.

Krzyżak T., Armia zagląda Papieżowi do talerza, „Plus Minus” dodatek do „Rzeczpospolitej” 30 VI - 1 VII 2018, s. 13-15.

Krzyżak T., Gajcy A., Armia PRL kontra Papież, „Plus Minus” dodatek do „Rzeczpospolitej", 9-10 VI 2018.

Michalski K., Działalność Komisji Wspólnej przedstawicieli Rządu PRL i Episkopatu Polski 1980-1989, Warszawa 2012.

Monat P., Dille J., Spy in the US, New York 1961.

Monat P., Dille J., Szpieg w Stanach Zjednoczonych (tłumaczenie z angielskiego), Zarząd II SG WP, Warszawa 1962.

Normatywy Wojskowej Służby Wewnętrznej (1957-1990), wyb., wst. i opr. B. Kapuściak, Katowice-Kraków 2019.

Pawlikowicz L., Tajny front zimnej wojny. Uciekinierzy z polskich służb specjalnych 1956-1964, Warszawa 2004.

Piotrowski T., Ucieczki oficerów Ludowego Wojska Polskiego w latach 1948-1990, „Więź” 1999, nr 12, s. 124-139.

Puciłowski J. OP, Portrety imienne i bezimienne. Polscy dominikanie a bezpieka 19451989, Kraków 2017.

Raina P., Anatomia linczu. Sprawa Ojca Konrada Hejmo, Warszawa 2006.

Raina P., Arcybiskup Dąbrowski - rozmowy watykańskie, Warszawa 2001.

Wiorko A., Dezercja, która wstrząsnęła przełożonymi, „Biuletyn Informacyjny AK” 2016, nr 9, s. 129-135.

Żaryn J., Dzieje Kościoła katolickiego w Polsce 1944-1989, Warszawa 2003.

\section{STRESZCZENIE}

\section{Bartosz Kapuściak, Wywiad wojskowy czy polityczny? Zainteresowanie Zarządu II Sztabu Generalnego Wojska Polskiego „kierunkiem watykańskim”}

Wywiad wojskowy PRL miał przede wszystkim za zadanie zdobywać materiały dot. uzbrojenia i stacjonowania wojsk NATO. Jednak ze względu na zapotrzebowanie władz komunistycznych prowadził także działania polityczne, wymierzone 
m.in. w Kościół katolicki. Zainteresowanie władz państwowych nasiliło się szczególnie w czasie pontyfikatu Jana Pawła II. Według oceny wywiadu wojskowego wybór Karola Wojtyły na biskupa Rzymu zaktywizował Kościół katolicki zarówno w kraju, jak i w Watykanie. Tym sposobem działania Zarządu II Sztabu Generalnego WP wchodzily w zakres zainteresowań wywiadu cywilnego.

Artykuł ma na celu pokazanie, jaką rolę odegrali oficerowie i współpracownicy wywiadu działający w Rzymie pod przykryciem attachatu wojskowego bądź placówek cywilnych. Ich działania doprowadziły do nawiązania kontaktów ze środowiskiem kościelnym oraz zdobycia świadomych i nieświadomych osobowych źródeł informacji.

W ten sposób Zarząd II SG WP przekazywał aparatowi partyjno-politycznemu ciekawe wiadomości i materiały. Wprowadzenie stanu wojennego w Polsce spowodowało, że Kościół z terenu Rzymu zaczął wysyłać do Polski paczki z żywnością, ubraniami i lekarstwami. Ta pomoc dla kraju została wykorzystana do nawiązania kontaktu z duchownymi polskimi dzięki inicjatywie płk. Franciszka Mazurka.

Słowa kluczowe: Zarząd II Sztabu Generalnego WP, wywiad wojskowy, rezydentura „Góra”, attachat w Rzymie, Kościół katolicki

\section{SUMMARY}

\section{Bartosz Kapuściak, Military or political intelligence? The interest of the Second Directorate of the General Staff of the Polish Army in the "Vatican direction”}

The primary task of the military intelligence in the People's Republic of Poland was to acquire materials on the armament and stationing of NATO troops. However, due to the demand of the communist authorities, it also conducted political activities aimed at, among others, the Catholic Church. The interest of the state authorities increased especially during the pontificate of John Paul II. According to the assessment of military intelligence, the election of Karol Wojtyła as Bishop of Rome stimulated the Catholic Church both in Poland and in the Vatican. In this way, the activities of the Second Directorate of the General Staff of the Polish Army were within the scope of civil intelligence interests.

The article aims to show the role played by intelligence officers and informers operating in Rome undercover as military attachés or in civilian institutions. Their actions resulted in the establishment of contacts with the church environment and acquisition of voluntary and involuntary informants. In this way, the Second Directorate of the General Staff of the Polish Army provided the party and political apparatus with interesting news and materials. Following the introduction of martial law in Poland, the church from the Rome area started sending parcels of food, clothes and medicines to Poland. This aid for the country was used to establish contact with the Polish clergy thanks to the initiative of Colonel Franciszek Mazurek.

Keywords: Second Directorate of the General Staff of the Polish Army, military intelligence, the "Góra" intelligence agency, attachés in Rome, the Catholic church 


\section{PE3ЮME}

\section{Бартош Капусчак, Военная или политическая разведка? Заинтересованность Управления II Генерального штаба Войска Польского „ватиканским направлением”}

Задачей военной разведки Польской Народной Республики было в первую очередь получение материалов о вооружении и размещении войск НАТО. Однако по требованию коммунистических властей он также вела политическую деятельность, связанную, в частности, с работой католической церкви. Интерес к ней государственных органов особенно усилился во время понтификата Иоанна Павла II. По данным военной разведки, избрание Кароля Войтылы епископом Рима активизировало католическую церковь как в стране, так и в Ватикане. Таким образом, деятельность Управления II Генерального штаба Войска Польского находилась в сфере интересов гражданской разведки.

Цель этой статьи - показать роль офицеров и сотрудников разведки, действующих в Риме под прикрытием военного атташе или гражданской заставы. Их действия привели к установлению контактов с церковной средой и приобретению сознательных и несознательных личных источников информации. Таким образом, Управление II Генштаба Войска Польского снабжало партийный и политический аппарат интересными новостями и материалами. Введение военного положения в Польше привело к тому, что костел из Рима начал отправлять в Польшу посылки с едой, одеждой и лекарствами. Эта помощь для страны была использована для установления контакта с польским духовенством благодаря инициативе полковника Франчишка Мазурка.

Ключевые слова: Управление II Генштаба Войска Польского, военная разведка, резиденция „Гура”, атташе в Риме, католический костел 
MiscellaneA BiograficZne

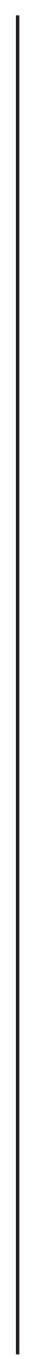

